\title{
AN APPLIED ANALYSIS OF THE RECYCLABILITY OF ELECTRIC VEHICLE BATTERY PACKS
}

By

\author{
Evan M Leon
}

\author{
A thesis submitted \\ in partial fulfilment of the requirements \\ for the degree of Master of Science \\ (Environment and Sustainability) \\ in the University of Michigan
}

April 2020

Thesis Committee:

Professor Shelie Miller, Chair

Professor Gregory Keoleian, Committee Member 

ABSTRACT: Current lithium-ion battery (LiB) recycling infrastructure is limited for strategic metals such as lithium and cobalt, despite projections that millions of electric vehicles (EVs) will hit the road in the next decade. Governments have labeled lithium and cobalt as "strategic" due to their importance in emerging green technologies as well as "critical" due to the increased risk of supply disruption resulting from geographic supply concentration, low substitutability, and low end-of-life recycling rates (EOLRR's). This paper aims to assist stakeholders conceptualize EV battery packs as a source of strategic metals and to help improve EOL-RR's for lithium and cobalt. Specifically, this paper demonstrates the value of EV battery packs as a source of metals compared to natural resources and outlines advantages and disadvantages of thermal and mechanical recycling processes in terms of energy consumption, variable costs and maximum recoverable metal value. Findings suggest that EV battery packs contain favorable concentrations - often 1 magnitude higher - of lithium, cobalt, nickel and copper compared to respective economic ores. Disassembling the EV battery pack to the cell level increases cobalt, lithium and nickel concentrations since they are part of the cathode active material. Between thermal and mechanical recycling processes, the key tradeoff is between process time and the ability to recover lithium. Thermal recycling requires less processing time than mechanical recycling, resulting in lower variable costs per battery pack, but mechanical recycling yields a higher maximum recoverable metal value since lithium can be recovered along with cobalt, copper and nickel.

KEYWORDS: metals recycling, recyclability, sustainability, secondary resources, electric vehicles, lithium-ion batteries

ABBREVIATIONS: End of life (EOL), Cathode Active Material (CAM), Greenhouse Gas (GHG), Lithium-ion battery (LiB), kilowatt-hour (kWh), British thermal unit (btu) 
ACKNOWLEDGEMENTS: The authors would like to acknowledge the Tozzi Electronic Business and Finance Center at the University of Michigan Stephen M. Ross School of Business for access to metal pricing data via Bloomberg.

This research did not receive any specific grant from funding agencies in the public, commercial, or not-for-profit sectors. 


\section{Table of Contents}

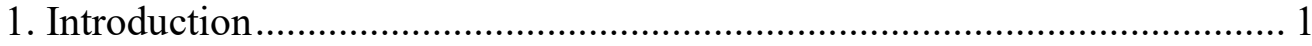

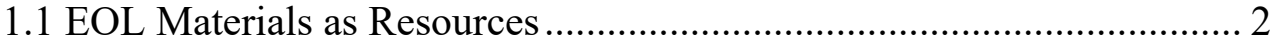

1.1.2 Calculations - EOL Material Mixing and Statistical Entropy vs. Thermodynamic Entropy ................................................................. 3

1.2 Lithium-ion Battery (LiB) Recycling Processes ................................ 4

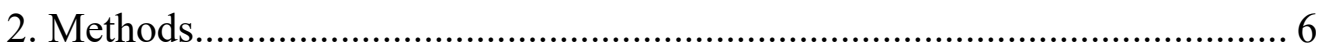

2.1 Calculating Energy Metal Concentrations in Battery Packs ................. 6

2.2 Sherwood Plot for Resource Attractiveness Evaluation ....................... 7

2.3 Statistical Entropy and Recyclability ........................................... 8

2.4 Modelling LiB Recycling Processes ................................................. 9

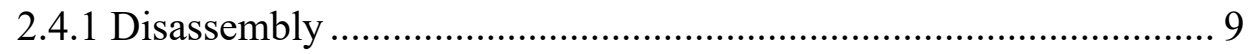

2.4.2 Mechanical Pre-Treatment......................................................... 9

2.4.3 Thermal Pre-Treatment.......................................................... 10

2.5 Recycling Process Energy Consumption and Costs .......................... 10

2.5.1 Energy Consumption ............................................................. 10

2.5.2 Variable Costs ................................................................... 11

2.6 Relating Statistical Entropy to Energy Consumption and Costs .......... 11

2.7 Maximum Recoverable Metal Value Calculation............................... 12

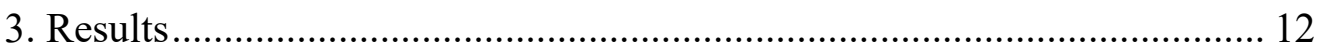

3.1 Battery Pack vs. Economic Ores.................................................... 14

3.2 Statistical Entropy of Battery Pack and Pre-Treatment Products ........ 15

3.3 Energy Modelling of Recycling Processes ........................................ 16

3.4 Cost Modelling of Recycling Processes ........................................... 17

3.5 Flow Rates, Process Times and Equipment Capacity........................ 18

3.6 Maximum Recoverable Metal Value .............................................. 19

4. Conclusions for Recyclability ............................................................ 19

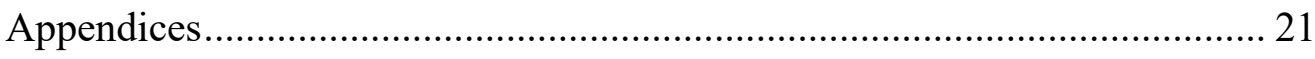

Appendix A.1: Metal Pricing Data ...................................................... 21

Appendix A.2: Economic Ore Grade Data (\%) ...................................... 22

Appendix A.3: Cobalt, Copper, and Nickel Grades by Ore Type ............. 23

Appendix B.1: Equipment List ......................................................... 24

Appendix B.2: Separation Steps Energy Efficiency per Bit of Entropy.... 24

Appendix B.3: Separation Steps Cost Efficiency per Bit of Entropy ........ 25 


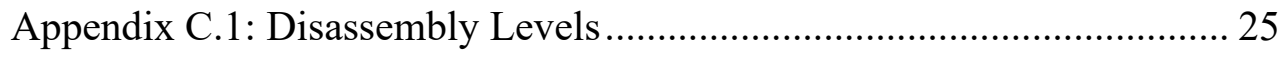

Appendix C.2: Pre-Treatment Processes …………………..................... 26

Appendix C.3: The LiB Recycling Process …………….......................... 27

Appendix D.1: Economic Recovery Scenarios.......................................... 28

Appendix D.2: Metal Price Sensitivity Analyses ……………………….... 30

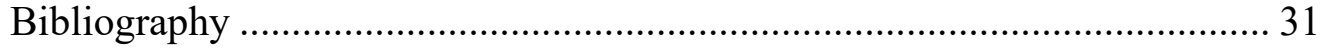




\section{Introduction}

In recent years, automotive manufacturers have generated significant public interest from the announcement of multi-billion dollar investment plans for Battery Electric Vehicle (BEV) production (Wall Howard, 2019)'(Sherman, 2018). BEVs are defined as electric vehicles (EVs) with only electrified powertrains, unlike plug-in hybrid electric vehicles (PHEVs) that use electrified powertrains and internal combustion engines. While the media and the public have focused primarily on the production and use phase of BEV battery packs, there have been fewer public statements regarding end-of-life (EOL) plans to capture battery packs' residual value. In China, recycling studies have identified BEV lithium-ion battery packs as part of a key reservoir for high-tech metals (Zuo et al., 2019). Battery packs are strong candidates for recycling because they often contain higher concentrations of specific metals, such as cobalt and lithium, than natural resources. Governments have labeled cobalt and lithium as "strategic" due to their importance to emerging green technologies (Bradley et al., 2017) as well as "critical" due to the increased risk of supply disruption resulting from geographic supply concentration, low substitutability, and low EOL recycling rates (Commission, 2017).

Current recycling infrastructure is limited for strategic metals such as lithium and cobalt, despite projections that millions of EVs will hit the road in the next decade. Overall, lithium-ion batteries' (LiBs) EOL recycling rate (EOL-RR) is estimated to be very low globally (Zeng et al., 2014)'(Zhan et al., 2018) and in China less than 10\% (Gu et al., 2017). In Belgium, roughly $24 \%$ of LiBs are accumulated in homes with 10-13.5\% ending up in landfills (Lizin et al., 2017). While the majority of LiBs available for recycling are from portable electronic devices and not EVs, the low recycling rates indicate a lack of a recycling system involving scaled recovery processes. In terms of metals recycling, metallurgical cobalt used in steel mattes, magnets and tools has an (EOL-RR) greater than $50 \%$, chemical cobalt used in battery materials is not tracked. Lithium in all forms has an EOL-RR less than $1 \%$ of all lithium placed in market via products and technologies (Graedel et al., n.d.).

There is a pressing need to understand 1) the degree to which the BEV battery pack is desirable for recycling and 2) the advantages and disadvantages of different recycling processes. This paper aims to assist stakeholders to conceptualize the BEV battery packs as a source of strategic metals and to help improve EOL-RR's for lithium and cobalt. Specifically, this paper quantifies the attractiveness of BEV battery packs as a source of metals compared to natural resources. Additionally, this paper models and discusses the energy consumption, variable costs, and maximum recoverable metal value from thermal and mechanical separation processes to better inform the battery recycling ecosystem of trade-offs between these processes. 


\subsection{EOL Materials as Resources}

Although the recycling infrastructure for specific commodities has existed for decades, the concept of EOL materials as sources of metal reserves is a relatively new concept. Starting in the early 2000's, material flow analysis (MFA) studies have calculated and assessed the metal stocks and flows associated with the EOL phase of automobiles (Dahmus and Gutowski, 2007), cell phones (Dahmus and Gutowski, 2007)'(Cucchiella et al., 2015)'(Zeng and Li, 2016a), lead-acid automotive batteries (Johnson et al., 2007), LiB cells (Zeng and Li, 2016a), LCD monitors (Cucchiella et al., 2015), and refrigerators (Johnson et al., 2007). One method of assessing whether the materials within a given technology are attractive for recycling is by comparing the concentration of metals in the technology to those of corresponding economic ores.

T.K. Sherwood's 1959 study of the relationship between chemicals' market prices and their dilutions in mixed streams serves as the seminal work for most studies of EOL recycling attractiveness. Sherwood captures the relationship between chemical dilution and market price on a log-log plot, asserting that magnitude increases in dilution are accompanied by equal increases in price (Sherwood and Ryan, 1959). For comparison to ore bodies, the dilution of a target metal in an ore is represented by the inverse of the target metal's ore grade.

As dilution and price increase on the log-log plot, plotted metal prices and metal dilutions in economic ores maintain a positive correlation across the log-log plot, representing the minimum price required to mine an ore with corresponding dilution. This plot is referred to as a "Sherwood Plot" and the correlation line is referred to as the cost-grade relationship (Holland and Petersen, 1995). In the context of recycling attractiveness, the line can be thought of as an economic recovery boundary. Several studies liken the Sherwood plot and economic recovery boundary to cut-off grades for ore extraction and processing in mining (Charles et al., 2017). If the ore does not meet a certain cut-off grade, it is not economical to mine. In turn, if the target metals in a product are highly diluted (i.e. to the right of the economic recovery boundary), recycling is less favorable than obtaining the metals from ore.

While the Sherwood Plot is not a definitive representation of resource economics due to various technical, economic, and socio-political complexities (Rudenno, 2012), Sherwood Plots and the economic recovery boundary can be useful for broad characterization of resource attractiveness (Dahmus and Gutowski, 2007)'(ALLEN and Behmanesh, 1994).

For metals recycling, the Sherwood Plot was first applied to compare the dilution of chromium, lead, and cadmium in industrial wastes to dilutions in economic ores, finding that waste streams have lower dilutions on average (i.e. higher concentrations) of each target metal than the corresponding economic ores.(ALLEN and Behmanesh, 1994) Since then, studies have confirmed that EOL products contain lower dilutions of certain target metals than most ores. 
Johnson et al. found that dilutions of copper, gold, silver and platinum in circuit boards and cell phones plot far to the left of the economic recovery boundary (Johnson et al., 2007)'(Cucchiella et al., 2015). In another study of precious metal concentrations in personal computer (PC) dynamic random access memory (DRAM) drives, the drives contained gold concentrations between 400 - 1000 ppm (Charles et al., 2017), which is 2 - 3 magnitudes higher than economic ore bodies grading 1-8 ppm (Rudenno, 2012).

This study adds to literature by applying the Sherwood Plot to an emerging technology, the BEV battery pack. The BEV battery pack's attractiveness as a source of lithium, cobalt, nickel and copper can be assessed by comparing its dilution of target metals to those in economic ores.

\subsubsection{Calculations - EOL Material Mixing and Statistical Entropy vs. Thermodynamic Entropy}

EOL technologies present significant challenges since they comprise materials that do not occur naturally together nor in the purities found in technologies, such as refined metallic pieces or alloys. In one recycling study, the average EOL technology contained 41 materials - presenting the opportunity for recovering multiple target metals (Cucchiella et al., 2015), but also the difficulty of separating mixed materials into useable forms. Studies have captured the degree of material mixing in EOL technologies by calculating statistical entropy. Statistical entropy captures the heterogeneity and proportionality of individual elements in a mixture. In product recycling, statistical entropy $(\mathrm{H})$ quantifies the number of binary separation steps to isolate a unique material within a mixed material product (Dahmus and Gutowski, 2007). Rooted in information theory, Claude Shannon quantified statistical entropy, $\mathrm{H}$, in his Noiseless Coding Theorem that estimates the average word length within given systems of discrete symbols. Shannon defined $\mathrm{H}$ as the summation of each symbol's probability of occurrence $p_{i}$ within the set of symbols multiplied by the natural logarithm of $p_{i}$ (Shannon and Weaver, 1964). $K$ is a constant that is used as a unit measure. Entropy $(H)$ is measured in bits.

$$
H=-K \sum_{i=1}^{n} p_{i} \log p_{i}
$$

\section{Equation 1: Statistical Entropy Function}

Contrary to the more traditional concept of entropy, statistical entropy does not quantify the amount of thermodynamic work required to attain a specific, and highly ordered, configuration of these materials. Since it does not measure thermodynamic work, statistical entropy cannot distinguish between physically and chemically mixed goods; rather, it captures the probability of encountering a unique material given the number and proportion of unique materials in a product. 
Statistical entropy has been used as a product recycling heuristic, a component of a product recyclability calculation, and as a metric in a recycling desirability index (Dahmus and Gutowski, 2007; Mohamed Sultan et al., 2017; Zeng and Li, 2016b). Gutowski and Dahmus use statistical entropy as a heuristic comparing a technology's sum of contained target metals prices and its statistical entropy to determine if it should be recycled. Graphically, the prices of contained target metals are on the y-axis in log scale and statistical entropy in bits $(\mathrm{H})$ is on the $\mathrm{x}$-axis - forming what is referred to as an apparent recycling boundary. The apparent recycling boundary uses statistical entropy calculations to compare the degree of material mixing in several products just like dilution is used to compare metal concentrations across ores. The difference is that statistical entropy can provide greater detail on the relationship between multiple targets metals and materials in one product whereas dilution only provides insight into the amount of one target metal in a mixture.

Statistical entropy is also used as a component of a broader recyclability calculation that combines a product's statistical entropy and the oxidation states of its chemically combined elements. This recyclability calculation contemplates the thermodynamic work required to break chemical bonds and distinguishes between physical and chemical mixing (Zeng and Li, 2016a).

In recycling desirability indexes, statistical entropy serves material separation calculation, which is combined with a technology readiness level (TRL) calculation and a material security calculation to compute a product's score on recycling desirability index (Mohamed Sultan et al., 2017).

In the present work, statistical entropies are calculated in bits at disassembly and pre-treatment levels to assess the efficiency of recycling steps in producing lower entropy or "purer" feedstocks for final recovery. Ultimately, the Sherwood plot combined with the Shannon calculation helps determine the recyclability of the battery pack - the ability to produce useable inputs that can be reintegrated in the battery supply chain.

\subsection{Lithium-ion Battery (LiB) Recycling Processes}

Most LiB recycling studies focus on recovering the LiB cells' cathode active material (CAM), which contains combinations of lithium, cobalt and nickel in the case of BEVs (Olivetti et al., 2017). The CAM presents significant incentive for recycling because it is reported to be the second largest material cost and GHG emissions contributor in battery manufacturing.(Ciez and Whitacre, 2019). The LiB recycling process is generally broken down into three stages: 1) disassembly; 2) pre-treatment that relies on mechanical or thermal separation; and 3) a final chemical treatment involving hydrometallurgy.

Academic literature has centered on chemical treatment, analyzing hydrometallurgical techniques and conditions to optimize leaching efficiency and metal recovery. Studies have primarily used mineral acids like nitric acid (Lee and Rhee, 2003), hydrochloric acid (Contestabile et al., 2001), and sulfuric 
acid (Shin et al., 2005). Processes using organic acids such as citric acid (Li et al., 2010), phosphoric acid, malic and acetic acids (Li et al., 2018) have also been studied since these acids carry fewer harmful environmental effects and are not associated with $\mathrm{NO}_{\mathrm{x}}$ and $\mathrm{SO}_{\mathrm{x}}$ gas creation. After acid leaching, solvent extraction is generally used to separate the nickel and cobalt (Gaines, 2018), allowing for individual metal recovery.

While academic literature provides ample guidance on chemical treatment processes that are scalable commercial volumes, there is a gap in literature regarding practical pre-treatment processes that are equally fit for industry. In academic studies, the pre-treatment processes employed in laboratory research are impractical for commercial volumes. Studies often describe the cutting open of cells with hand tools (Li et al., 2010)'(Contestabile et al., 2001), and the unwinding of the electrode jelly roll by hand (Chen et al., 2017) followed by the soaking of electrodes in N-methyl pyrrolidone (NMP) solvent to remove the CAM from the current collector (Contestabile et al., 2001)'(Chen et al., 2017); however, NMP is costly and not suitable for scaled recycling operations (Yao et al., 2018). Even when using machinery for disassembly and physical separation, it is often small scale, such as planetary ball mills (Li et al., 2010) or household blenders (Sloop et al., 2018)'(Zhan et al., 2018).

There is a need to examine scalable thermal and mechanical pre-treatment techniques that can produce valuable feedstocks for reintegration in the supply chain. Currently, thermal processes involving pyrolysis and smelting appear to be the only scaled industrial processes that recover cobalt, nickel and copper in a matte (Kushnir, 2015); however, they do not recover lithium or aluminum, which are captured in the silica-based slag (Sonoc et al., 2015)'(Gaines and Dunn, 2014)'(Kushnir, 2015)'(Diekmann et al., 2017).

For mechanical separation, the LithoRec Process exemplifies the use of shredders, industrial dryers, cutting mills, and vibrating sieves to achieve physical separation of cell components (Diekmann et al., 2018). Starting in an inert environment with nitrogen gas, modules are shredded, then dried to burn off carbon additives and binder, causing the active material to separate from the current collector (Diekmann et al., 2017). This is followed by a second cutting mill and vibrating sieve to isolate the cathode material and few copper and aluminum impurities in a material called "Black Mass." Similarly, Retriev Technologies begins with a cryogenic process using liquid nitrogen that freezes cells, rendering the lithium inactive before shredding, followed by recovery of different metal fractions using hammer mills, shaker tables and carbon filter presses (Sonoc et al., 2015). In both processes, cobalt, nickel, aluminum, copper and lithium are recovered in different forms.

Disassembly should not impact the amount of lithium or cobalt available recovery; however, the pre-treatment process- mechanical or thermal - can have significant impacts on 1) the metals available for recovery and 2) the amount of each metal available for final treatment. While hydrometallurgy will be required for chemical treatment, it is unclear whether industry will use 
thermal or mechanical pre-treatment to treat millions of battery packs at endof-life. This paper assesses the advantages and disadvantages of each pretreatment process in terms of energy consumption, variable cost, and maximum recoverable metal value.

\section{Methods}

This paper determines the recyclability of lithium, cobalt, copper, and nickel within battery packs used for electric vehicles. From Argonne National Laboratory's BatPac Model Version 3.1 (June 2018 Release), we use the bill of materials for Battery \#3 (79.4 kWh) with the cathode active material (CAM) nickel-manganese-cobalt oxide (NMC 622) as the basis for our analysis (See "Recycle" tab in BatPac Model) (Nelson, Paul; Gallagher, Kevin; Bloom, Ira; Dees, Dennis; Ahmed, 2018). Within the NMC chemistries, we select the ratio 622 (Ni:6, Mn: 2, Co:2) since it is currently commercializable (Olivetti et al., 2017)'(Turk and Cazzola, 2018).

The battery pack's resource attractiveness is assessed by constructing a Sherwood Plot and comparing the dilution of metals in the battery pack to the dilution of metals in economic ores. On the same plot, an economic recovery boundary is constructed using average economic ore grades and average annual market prices for 20 metals (See Appendices A.1 and A.2). By comparing the metal dilutions in the battery pack with those in economic ores, the battery pack's resource attractiveness at EOL can be quantified by calculating the amount of each resource (battery pack or ore) required to produce a unit of cobalt, copper, lithium and nickel.

After assessing resource attractiveness, statistical entropy is calculated at disassembly levels (See Appendix C.1) and pre-treatment products (See Appendix C.2). Statistical entropy is used as a product recycling heuristic to quantify the degree of material mixing by measuring the number of bits - the binary separation steps required to isolate a single pure metal from the recycling stream. In addition to statistical entropy, we model the energy requirements and variable costs of disassembly, mechanical and thermal pre-treatment per battery pack.

\subsection{Calculating Energy Metal Concentrations in Battery Packs}

To determine the concentration of target energy metals, mass-based calculations were completed at different disassembly levels: cell, module and battery pack. The cell contains current collectors, active materials, polymer separators, and electrolyte that are sealed in a polymer pouch. Each module houses 12 cells. The battery pack comprises 20 modules and a total of 240 cells. Based on the BatPac Model, the battery management system (BMS) and the cooling system are not evaluated for recyclable metal content. 


$$
\begin{aligned}
& \text { Target Energy Metal Concentration } \\
= & \frac{\text { Target Energy Metal Contained }_{\text {grams }}}{\text { Battery System Level }} \text { grams }_{\text {Sram }}
\end{aligned}
$$

Mass-based calculations are also completed for the two pre-treatment products: mixed active materials and the matte of CAM metals and copper current collector. Mixed active materials consist of the CAM transition metals, carbon black additives, oxygen, and graphite anode active material. The matte contains nickel, cobalt, and manganese, along with copper anode current collector. The electrolyte's lithium is assumed to not be recovered and thus does not contribute to the energy metal concentrations below. In previous studies, the electrolyte is not considered a high value material for recycling (Wang et al., 2014).

Table 1: Energy Metal Concentrations in NMC 622 BEV Battery Pack \#3 and

\begin{tabular}{|c|c|c|c|c|c|}
\hline & $\begin{array}{c}\text { Thermal } \\
\text { Pre- } \\
\text { Treatment }\end{array}$ & $\begin{array}{c}\text { Mechanical } \\
\text { Pre- } \\
\text { Treatment }\end{array}$ & \multicolumn{3}{|c|}{ Disassembly Level } \\
\hline $\begin{array}{c}\text { Recoverable } \\
\text { Metal }\end{array}$ & Matte & $\begin{array}{c}\text { Mixed } \\
\text { Active } \\
\text { Materials }\end{array}$ & Cell & Module & $\begin{array}{c}\text { Battery } \\
\text { Pack }\end{array}$ \\
\hline Cobalt & $10.00 \%$ & $8.00 \%$ & $4.01 \%$ & $3.72 \%$ & $2.87 \%$ \\
\hline Copper & $36.00 \%$ & N/A & $16.59 \%$ & $16.59 \%$ & $12.80 \%$ \\
\hline Nickel & $29.88 \%$ & $23.91 \%$ & $12.86 \%$ & $11.92 \%$ & $9.20 \%$ \\
\hline Lithium* & $\mathrm{N} / \mathrm{A}$ & $5.30 \%$ & $2.66 \%$ & $2.47 \%$ & $1.90 \%$ \\
\hline
\end{tabular}
Pre-Treatment Products

* Lithium concentrations do not account for lithium present in the electrolyte - Lithium Hexafluorophosphate - $\mathrm{LiPF}_{6}$.

As indicated in Table 1, target energy metals - except for lithium - are present in the highest concentrations in thermal pre-treatment's matte. The matte reports higher concentrations than the mechanical pre-treatment's mixed active materials since it does not include the graphite anode materials, the oxygen from the CAM's transition metal oxide, nor the carbon black additives. Disassembly increases target metal concentrations and improves secondary resource attractiveness - a key finding in previous studies (Johnson et al., 2007).

\subsection{Sherwood Plot for Resource Attractiveness Evaluation}

The Sherwood Plot is constructed to assess the battery pack's resource attractiveness by plotting the metal prices and ore dilutions on a log-log plot. For the target metals - lithium, cobalt, nickel and copper - ranges of dilutions 
based on ore body type are plotted (See Appendix A.2). Prices plotted are the average calendar year 2017 price in USD per quantity sold. Quantity sold is adjusted to kilogram, i.e. USD\$ per $\mathrm{kg}$, from the quoted quantity in Appendix A.1.

For nickel, cobalt and copper, Tisserant and Pauliuk's data set is used to segment global ore grades by resource type and target metals present (Tisserant and Pauliuk, 2016). For lithium, Mohr and Mudd's data set for both lithium rock and brine resource grades is used and adjusted to include resources in production (Mohr et al., 2012). Additionally, the dilutions of target metals at the battery pack, module, cell disassembly levels are calculated. Based on the ore body types and disassembly levels in Appendix A.3 and Table 1 respectively, each target metal will have three unique data points for its ore dilutions and three points for battery dilutions.

The ore dilution data points are combined into a single global average dilution for each target metal. Using the global average dilution and market price for each metal, a power trend line of best fit is created to represent an economic recovery boundary. Assuming processing costs increase with the amount of raw material feedstock (i.e. metric tons of the ore body and/or the battery packs), the plot suggests that a magnitude increase in dilution will result in a magnitude increase in price per unit. All data points to the left of the boundary are economically feasible while those to the right of boundary are either too dilute or do not have a sufficient market price.

\subsection{Statistical Entropy and Recyclability}

Statistical entropy is applied as a product recycling heuristic at disassembly levels and pre-treatment states to quantify the degree of material mixing and assess the difficulty to recover individual metals for reintroduction into the battery supply chain. Using the statistical interpretation of entropy established by Shannon, materials that are mixed in increasingly heterogenous forms will encompasses more uncertainty when determining the probability of encountering a material in a mixed material stream. Manufactured technologies, like battery packs, represent high statistical entropy states since they comprise many unique materials that have been formed, stamped, molded, and soldered together. Recycling should transform technologies from high entropy states to lower ones, yielding "purer" feedstocks for final recovery.

Statistical entropy is measured in bits $(\mathrm{H})$, which represent the number of binary separation steps to isolate a single material in the recycling stream. Relying on Shannon's principle that entropy $\mathrm{H}$ is additive, the battery pack's entropy is conceived to be the weighted sum of the entropies at each disassembly levels in the battery pack. Using the BatPac Model's "Recycle Tab," mass-based concentrations of all unique metals and materials (i.e. binder chemicals) were calculated at the different battery disassembly levels and pre-treatment products. These concentrations are used as the probability variables $\left(p_{i}\right)$ in the statistical entropy function defined in Section 1.1.2. The sum of the statistical 
entropy functions for each variable (i.e. concentration) $\left(P_{i}\right)$ equals the statistical entropy (in bits) of that disassembly level or pre-treatment product.

\subsection{Modelling LiB Recycling Processes}

To conceptualize the $\mathrm{LiB}$ recycling process, we have outlined the system boundaries as follows: 1) disassembly; 2) pre-treatment (mechanical or thermal separation); and 3) chemical treatment using hydrometallurgical techniques. These system boundaries are largely in line with those discussed in other recycling studies (Diekmann et al., 2018) (See Appendix C.3).

\subsubsection{Disassembly}

The disassembly process includes no automation and assumes two high voltage technicians (Diekmann et al., 2018) using basic hand tools for two hours to disassemble the battery pack to the cell level. We assume that the pack is fullydischarged to reduce fire risk originating from short circuit (Sonoc et al., 2015). Given that recyclers will be treating battery packs from multiple manufacturers, we assume automation will be difficult due to the variety of pack and module designs (Gaines, 2018)'(Herrmann et al., 2012). Additionally, studies indicate manual disassembly will likely be required to dismantle battery systems to modules and to expose cells inside modules. Automation can be used to discharge packs below cutoff voltages and to remove the exposed cells from modules; however, the present work does not contain such automated methods (Herrmann et al., 2012). Finally, our process assumes disassembly to the cell level, which differs from other thermal and mechanical processes that disassemble to the module level (Diekmann et al., 2017; Tytgat, 2013). Since there is no standardized module design among manufacturers, disassembly to the cell provides more volumetric flexibility in how materials are fed into equipment and allows cells to be tested for repurposing in other energy storage applications.

\subsubsection{Mechanical Pre-Treatment}

A mechanical pre-treatment process is adapted from Diekmann et al.(Diekmann et al., 2018) with minor changes: 1) the presence of conveyor belt systems between machinery and 2) no second air classification to separate current collector foils and separators. Fully discharged cells are processed in an industrial shredder with an inert environment to prevent combustion of hydrogen fluoride (HF) gas generated by electrolyte evaporation. To separate active materials from current collectors, shredded material is placed in an industrial dryer at 100 Celsius. Diekmann's pilot scale literature indicates drying is conducted for one hour depending on the technology (Diekmann et al., 2018); however, Diekmann's original paper cites five hours (Diekmann et al., 2017). In the present work, we model the drying time from pilot plant literature as it is likely more representative of commercial scale. The subsequent air classification step separates materials based on density, using forced air to separate low-density polymer cell casings and plastic separators from higher 
density active materials, aluminum and copper foils. Cutting mills reduce the particle size of the higher density fraction. Finally, a vibrating gravity sieve is used to separate materials based on particle size to remove residual copper / aluminum foils and recover "black mass" - a mixture of active materials and carbon black. This sieve is likely be 250 micron to separate active materials with few copper impurities (Gratz et al., 2014). We assume two semi-skilled plant operators manage the process.

\subsubsection{Thermal Pre-Treatment}

The thermal pre-treatment process is based on commercialized pyrometallurgical battery recycling processes (Diekmann et al., 2017; Gaines, 2018; Ordoñez et al., 2016) that rely on natural gas-fired furnaces. During thermal treatment, the cells' electrolyte and PVDF binders evaporate, plastics and polymers casing combust, and more importantly, the active materials are reduced, breaking the chemical bonds in the CAM's transition metal oxide and removing the carbon black additives and graphite anode materials. This process yields a matte of transition metals - nickel, cobalt, manganese and copper. Aluminum and lithium are captured in a silicon-containing slag that appears uneconomic to process (Gaines, 2018; Kushnir, 2015). We assume two plant operators are required to monitor the furnace.

\subsection{Recycling Process Energy Consumption and Costs}

Based on Section 2.4, we selected equipment used in the material processing and recycling industries with publicly available specifications (See Appendix B.1). All energy consumption and variable costs are calculated on a $\mathrm{kWh}$ or U.S. dollar (\$) per battery pack basis.

\subsubsection{Energy Consumption}

For disassembly energy consumption, each high voltage technician is assumed to consume $16,000 \mathrm{~kJ}$ per 24-hour period (Schobert, 2014). Disassembly is assumed to require two hours and two technicians, equating to 2,667 kJ per battery pack.

To calculate mechanical pre-treatment energy consumption, we determine the appropriate size and capacity of each piece of equipment required and the processing time. The industrial shredder and its theoretical processing rate of 55 battery packs per hour (roughly 13,200 cells) is used as the basis for all other equipment sizes. The industrial shredders' processing time per battery pack is calculated based on cell dimensions, feed opening dimensions, and the shredder blades' circumference and rotations per minute. Processing time per battery pack is multiplied by the manufacturer-specified power requirements to calculate energy consumption in $\mathrm{kWh}$ per battery pack.

In addition to the shredder, equipment was sized based on cell dimensions and the aggregate cell volume on a battery pack basis. For simplicity, we assumed 
that shredded cells retain the same volume as before shredding. Additionally, after the first air classification, we assume all polymer casing and separators were removed - resulting in a $20 \%$ linear reduction in mass and volume. For the cutting mill and vibrating sieve, processing time was calculated with the post-air classification volume - $80 \%$ of pre-air classification volume.

Processing times are from literature, such as the industrial dryer, or calculated by multiplying the work area of each equipment by the optimal feed rates in linear length (feet, centimeters, millimeters) per second, such as the shredder and cutting mill. For the vibrating sieve, processing time is assumed to be three minutes per battery pack. Since there is no conveyor belt between the air classification system, cutting mill, and vibrating sieve, all equipment is assumed to be operational for the duration of the sum of each machine's processing times.

Thermal pre-treatment energy consumption is based on the amount of input energy required to treat one metric ton of battery scrap - $0.69 \mathrm{mmbtu}$. This is based on data from Umicore, the Belgian materials technology and recycling group, cited in literature (Dunn et al., 2014). The energy required per battery pack is calculated by dividing by the number of battery packs per ton of battery scrap. Given that cell mass from one battery pack is $343.2 \mathrm{~kg}$, there are approximately 2.91 battery packs in one ton of battery scrap (Jones et al., 1997). In the absence of a thermal pre-treatment process time in literature, a patent review of thermal battery recycling processes yielded furnace residence times as short as 26 minutes for cobalt-containing lithium-ion batteries (阿部, 1993) and 30 minutes for zinc, cadmium, lead and alkaline batteries,(Hanulik, 1995) respectively. We assumed a minimum process time of 30 minutes per battery pack since the mechanical processing time is also representative of minimum process time for shredding and sieving.

\subsubsection{Variable Costs}

Variable costs related to energy and labor are calculated using process times per battery pack in Section 2.5.1. For energy, the Energy Information Administration's FY2017 average industrial electricity rate -6.88 cents per kWh (U.S. Energy Information Administration, 2019a) and average industrial natural gas price - $\$ 4.10$ per thousand cubic $\mathrm{ft}$ (HHV) (U.S. Energy Information Administration, 2019b) are used. For labor, there are two hourly pay scales: high voltage technician - US\$25 per hour and plant operator - US $\$ 45$ per hour.

\subsection{Relating Statistical Entropy to Energy Consumption and Costs}

Statistical entropy calculations assume that the battery pack is disassembled in a series of binary separation steps. At each binary separation step, substances are removed, reducing statistical entropy as the remaining battery components advance to the next step. The energy and cost efficiency of each step is

calculated by dividing the energy consumed or variable cost incurred in the step $(\mathrm{kWh}$ or \$) by the reduction in statistical entropy (in bits). 


\subsection{Maximum Recoverable Metal Value Calculation}

Previous studies have presented "commodity value" calculations(Wang et al., 2014) that assess the maximum recoverable metal value based on the battery cells' contained metal content and average market prices. Taking it one step further, we incorporate recovery efficiencies for the disassembly and pretreatment processes. These efficiencies are subsequently multiplied by the battery pack's metal content and respective FY17 average metal prices. For disassembly, we assumed $90 \%$ recovery efficiency of contained copper and aluminum from the module and battery pack levels. For thermal pre-treatment, recovery efficiencies range from $80-90 \%$ (Kushnir, 2015) while efficiencies of $72.5 \%$ (Diekmann et al., 2017) - 80\% (Diekmann et al., 2018) are used for mechanical pre-treatment. The $72.5 \%$ figure is assumed to be mixed active materials (i.e. "Black Mass") net of copper, aluminum, and other impurities. The same recovery efficiency is assumed for each metal in each process.

\section{Results}

On our Sherwood Plot in Figure 1, target metal market price and average dilution in economic ores maintain a statistically significant positive correlation. A magnitude increase in dilution generally equates to a magnitude increase in price. This is evident when comparing common metals (i.e. chromium, tin, aluminum, and lead) with semi-precious and precious metals like silver, gold and platinum group elements. Silver's dilution is roughly three magnitudes higher than chromium (17380.95 vs. 6.48) and consequently has a market price three magnitudes higher ( $\$ 601.75$ vs. $\$ 0.26$ per $\mathrm{kg}$ ). This analysis supports Thomas Sherwood's findings as well as those in previous analyses 
(Dahmus and Gutowski, 2007)'(ALLEN and Behmanesh, 1994; Johnson et al., 2007).

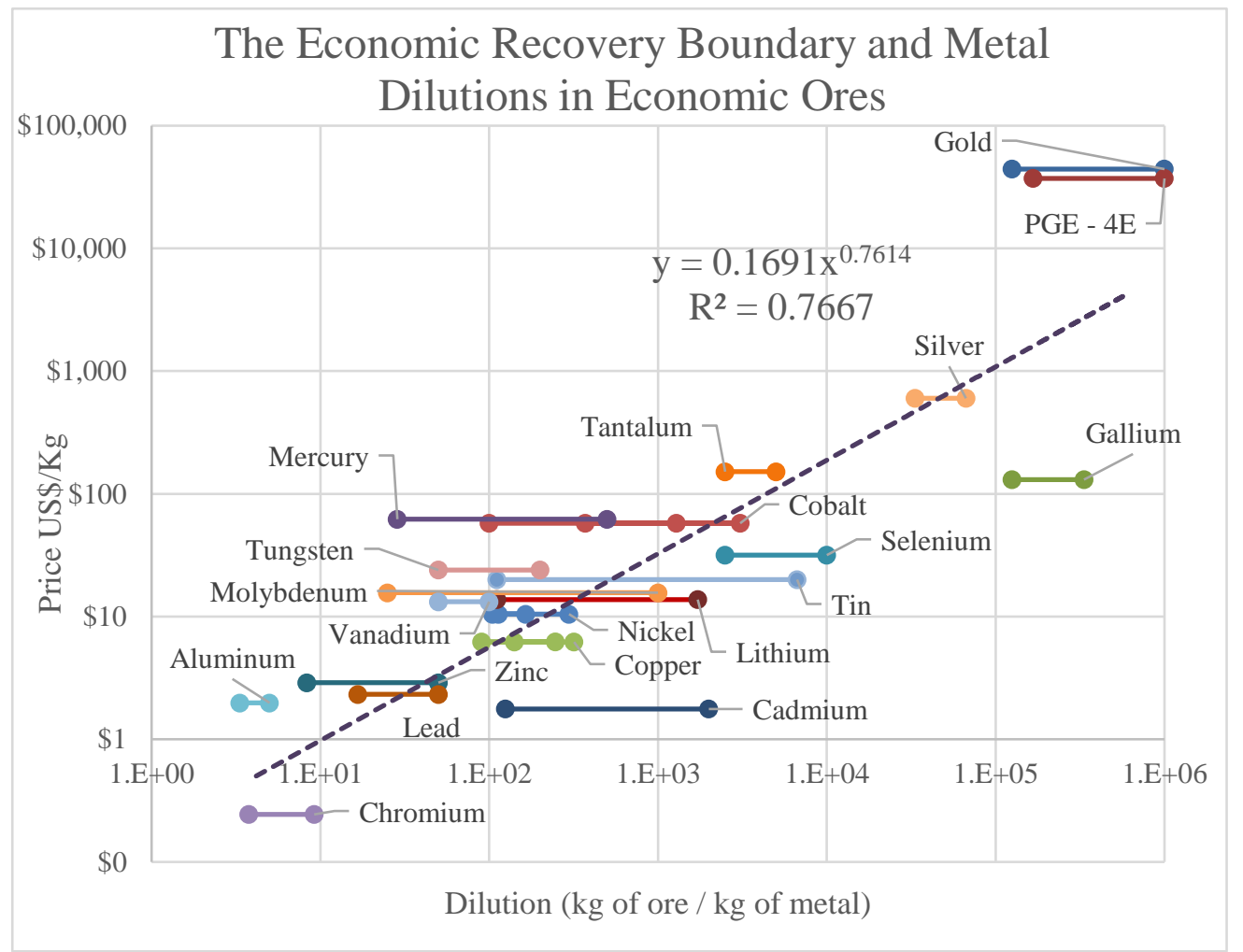

Figure 1: The Economic Recovery Boundary and Metal Dilutions in Economic Ores Horizontal bars represent the dilution range for each metal's ore plotted on the $x$-axis; Bars' vertical position on $y$-axis is based on the FY17 US\$ average price per kilogram. The economic recovery boundary is the dotted line of best fit based on the average dilution for each metal and price.

The power line of best fit (----) represents the "Economic Recovery Boundary," which symbolizes the economic dilution of a target metal required for processing an ore. Our economic recovery boundary captures over $70 \%$ of the variation between average metal dilutions in ores and price. Dilutions to the left of the economic recovery boundary are considered economic.

Several target metal dilutions may appear to be uneconomic; however, it is important to consider other factors in resource economics. First, metals usually occur in combinations in ore bodies. For example, cobalt is a companion metal to other base metals like copper and nickel. Low cobalt grades are often compensated by high copper grades in copper-cobalt resources and vice versa. On the secondary resource side, battery packs also contain a combination of target metals with each one contributing to the pack's residual value - cobalt, nickel, lithium, and copper. In addition to multiple target metals, process technologies may allow ores with high dilution of target metals to become economically viable. With lithium, brine evaporation processes allow salt brine 
resources with dilutions roughly 1x magnitude higher than hard rock resources to be economical. The Salar de Atacama, a brine resource, has a lithium dilution of roughly 666.67 whereas Greenbushes, a hard rock resource, has a dilution of 52.63 (Mohr et al., 2012).

\subsection{Battery Pack vs. Economic Ores}

In Figure 2, dilution ranges of lithium, copper, cobalt, and nickel at different battery pack disassembly levels are compared to those in economic ores from Figure 1. All battery pack dilutions plot to the left of the economic recovery boundary, confirming that the battery pack is well-suited for recycling based on metal content. Each metal's horizontal bar represents a dilution at a disassembly level from the battery pack (far right point on bar) to the cell (far left point on bar). At the battery pack level, without any disassembly, copper and nickel dilutions are roughly $1 \mathrm{x}$ magnitude lower than the best nickel and copper containing ores. For perspective, to produce 1 metric ton of nickel metal, it would require 10.1 metric tons of battery pack ( 24 battery packs) compared to 105 metric tons of the highest-grade nickel-bearing ore. Similarly, 8 metric tons of battery pack (19 battery packs) would be required to produce 1 metric ton of copper compared to 90.2 metric tons of the highest-grade copper-bearing ore.

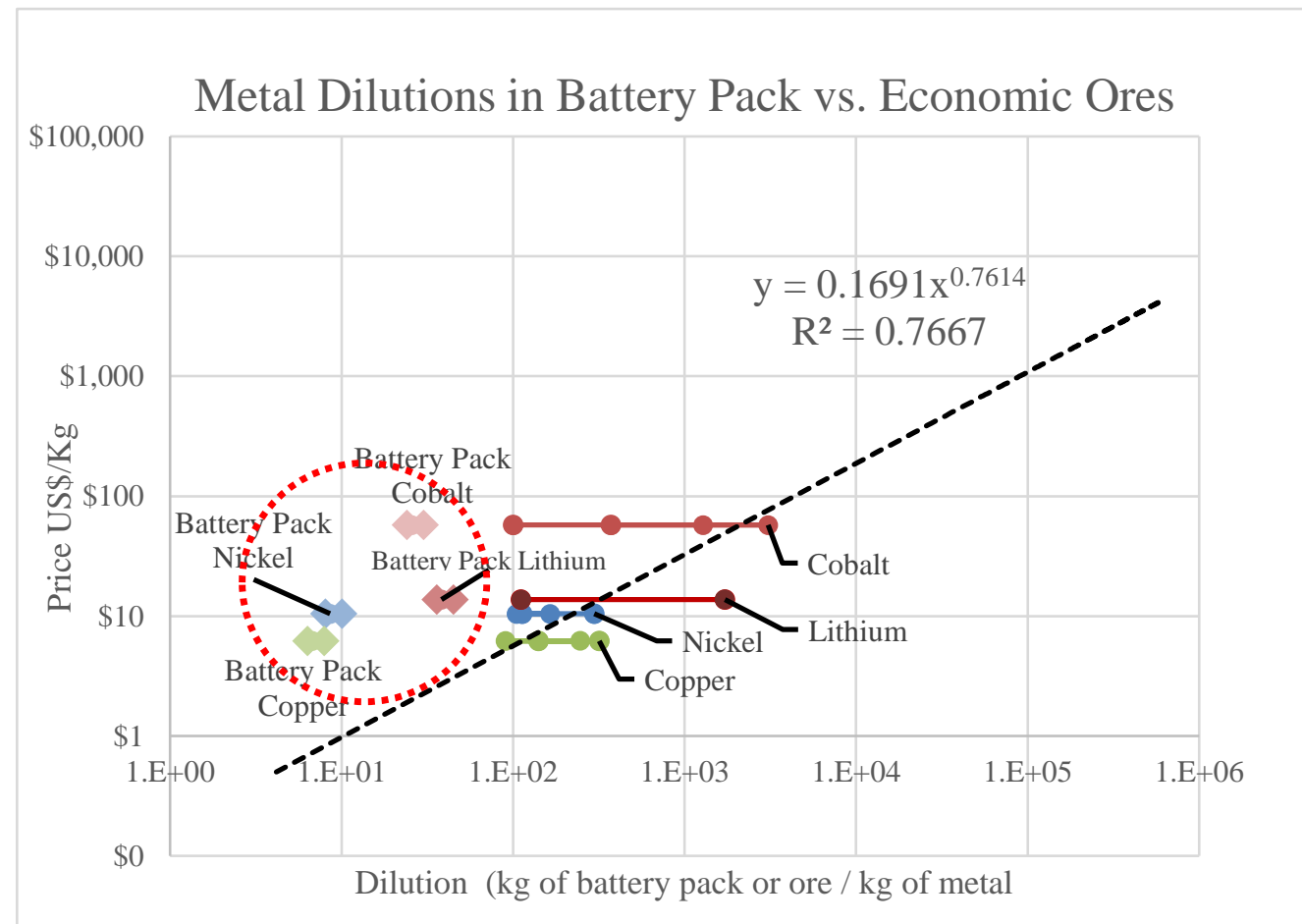

Figure 2: Metal Dilutions in Battery Pack vs. Economic Ores - Dilutions of metals in the battery pack (circled) are favorable to corresponding dilutions in economic ores, indicating the battery pack is an attractive resource.

For lithium and cobalt, resource attractiveness is less strong at the battery pack; however, disassembly to the cell decreases dilution by at least $20 \%$ for both metals since they are constituents of the CAM. Even at the battery pack level, 
it would require 30 metric tons of battery pack to produce 1 ton of cobalt metal compared to 100 tons of the best cobalt-bearing ore. When disassembly to the mixed active material level is considered, only 13.15 metrics of mixed active materials would be required to produce 1 ton of cobalt metal - incredibly favorable for a metal that typically grades less than $1 \%$.

For nickel, disassembly also yields a similar 20\% improvement in dilution since nickel is the primary transition metal in NMC 622. Copper dilution is also improved with disassembly, but to a lesser extent, resulting in $16 \%$ decrease in copper dilution from the battery pack to cell disassembly level. Disassembly has a lesser effect on copper dilution reduction because copper is present at the module and pack in meaningful quantities; however, the bulk of the battery pack's copper (76\%) is contained in the cells since copper foil is used as the anode current collector.

Based on improvements in dilution alone, EV battery pack's nickel and copper appear to merit recycling the most compared to their natural resource counterparts; however, cobalt is the clear metal value driver of LiB recycling with the most favorable combination of market price and dilution of any target metal. Our graphical representation supports previous authors assertions about battery waste being bought and sold based on cobalt content (Gaines, 2018)'(Diekmann et al., 2018)'(Ciez and Whitacre, 2019).

\subsection{Statistical Entropy of Battery Pack and Pre-Treatment Products}

Statistical entropy and energy consumption analyses complement the Sherwood plot by 1) highlighting which binary separation step has the greatest impact in reducing entropy and 2) indicating the relative energy and cost efficiencies of mechanical and thermal pre-treatment processes.

Battery pack level entropy is calculated to be 2.85 bits. During manual disassembly to the cells, statistical entropy decreases to 2.48 , roughly $13 \%$ reduction in entropy; however, pre-treatment yields the greatest decrease in entropy. Thermal pre-treatment appears to reduce entropy by $46 \%$ to 1.35 bits while mechanical reduces entropy by only $32 \%$ to 1.70 bits.

As shown in Figure 3, thermal pre-treatment generates a product with a lower statistical entropy than mechanical; however, mechanical pre-treatment's mixed active materials contain almost twice the number of unique materials than the thermal treatment's matte product. In terms of proportionality, thermal pre-treatment's matte appears to be more proportionally heterogenous than the mixed active materials, a characteristic that reduces purity and contributes unfavorably to statistical entropy. Despite having half the number of unique materials, the matte's statistical entropy is 1.35 bits - only $21 \%$ less than mixed active materials -1.70 bits. 


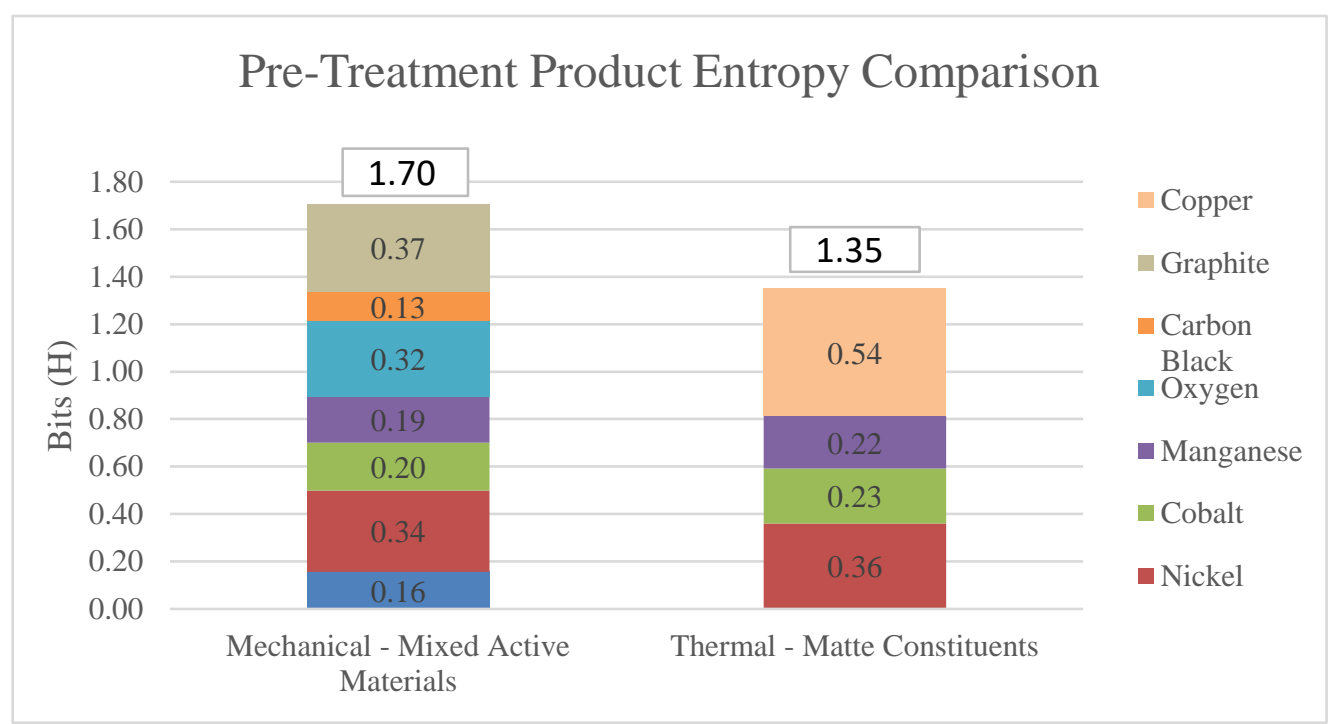

Figure 3: Pre-Treatment Product Entropy Comparison - Mixed active materials report a higher entropy figure (1.70 bits) than the matte product (1.35 bits) because the mixed active materials has almost twice the number of unique elements. The matte is more proportionally heterogenous, which increases its statistical entropy despite having half the elements.

We were unable to find a statistical entropy calculation for a BEV battery pack in literature; however, Zeng et al. calculates the statistical entropy for a LiB cell to range from 1.8 to 2.1 bits (Zeng and Li, 2016a) - lower than our calculation of 2.48 bits. There are several reasons why our results differ from Zeng et al. In Zeng et al.'s statistical entropy calculation, the CAM could be treated as a singular substance while our study treats each element in the CAM as a unique substance with a probability of occurrence, which increase entropy. When active materials are treated as singular substances in the present study, the cell's statistical entropy is 1.89 bits - in line with Zeng's calculation range. We choose to calculate entropy at the elemental level to compare mechanical and thermal pre-treatment processes since thermal processing separates cathode materials into a matte comprising elemental metals. Zeng's calculation may also be lower if a different CAM, such as lithium cobalt oxide (LCO), was modeled in the statistical entropy calculation. The CAM modeled in this study, NMC 622, contains two more elements than LCO and is more proportionally heterogenous, meaning that it will report a higher statistical entropy than LCO.

\subsection{Energy Modelling of Recycling Processes}

Thermal pre-treatment consumes $40+\mathrm{kWh}$ more energy per battery pack than mechanical pre-treatment due to the furnace's higher energy requirements compared to mechanical pre-treatment equipment. Other studies suggest that shaft furnaces require $5000 \mathrm{MJ}$ of energy per metric ton of battery waste.(Sonoc et al., 2015) When this figure is converted to $\mathrm{kWh}$ and attributed to the Battery Pack \#3 cell mass (341.57 kg), energy consumption totals $474.35 \mathrm{kWh}$ per battery pack - further substantiating that thermal pre-treatment requires at least two times the energy that mechanical requires. It is important to note that the bulk $(80 \%)$ of the mechanical pre-treatment energy consumption is related to 
the air classification step, which separates metals from polymer casing / separators based on density (Diekmann et al., 2017). Mechanical pre-treatment could be even more efficient if less energy-intensive air classification equipment is identified.

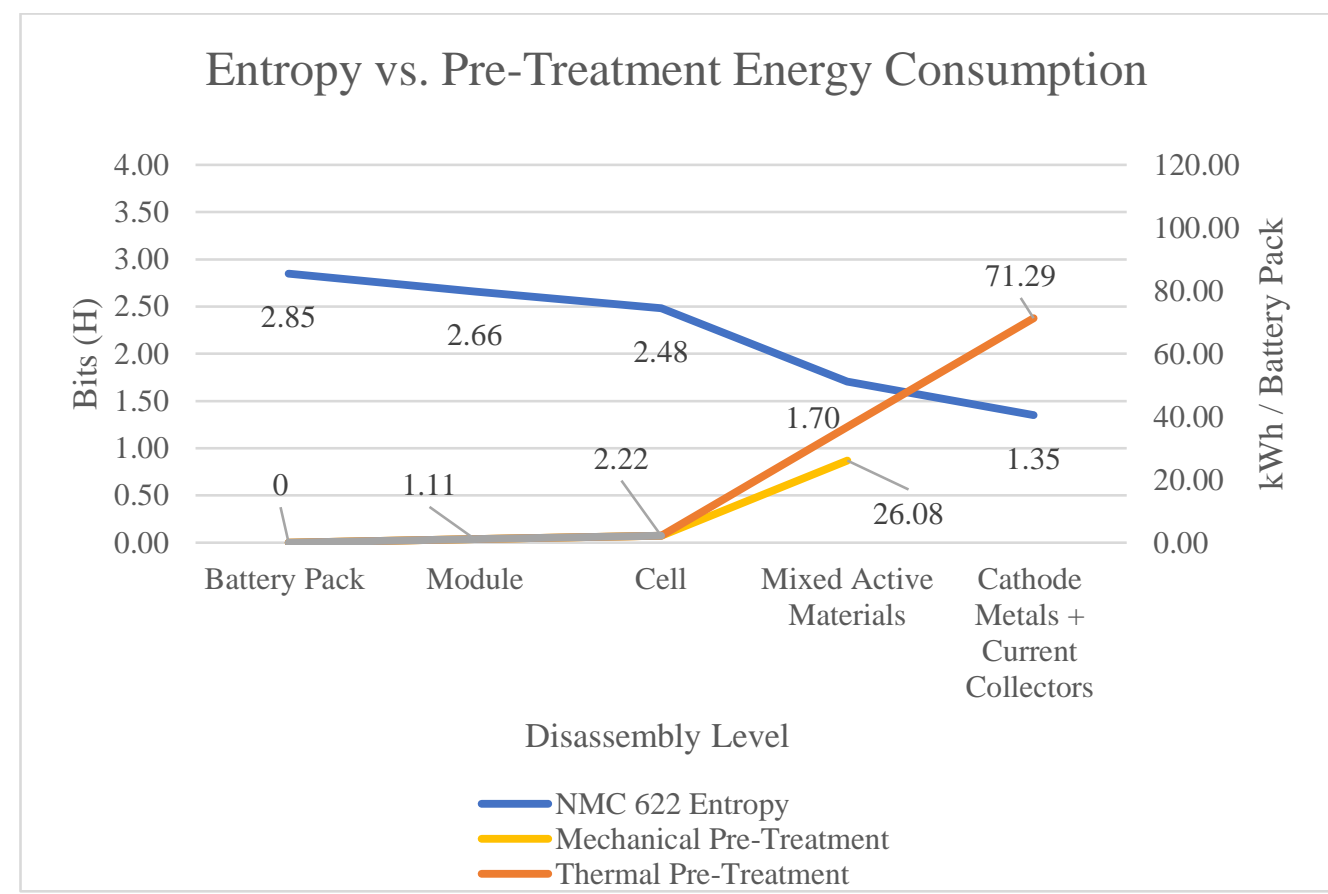

Figure 4: Entropy vs. Pre-Treatment Energy Consumption - Thermal Pre-Treatment requires 2.73 more times energy (71.29 vs. $26.08 \mathrm{kWh}$ ) than Mechanical Pre-Treatment to achieve only $15 \%$ more statistical entropy reduction. Mechanical Pre-Treatment is a much more energy efficient process for reducing statistical entropy.

Each separation step's energy consumption in kWh per bit of is calculated. Mechanical pre-treatment requires $33.44 \mathrm{kWh}$ per bit of entropy reduced much more efficient than thermal pre-treatment's $63.09 \mathrm{kWh}$ per bit. Overall, disassembly still yields the most favorable energy efficiency of all separation steps $(6.08 \mathrm{kWh}$ per bit), highlighting the lower energy intensity of human labor versus machinery (See Appendix B.2).

\subsection{Cost Modelling of Recycling Processes}

After disassembly, thermal pre-treatment requires roughly one-half of mechanical pre-treatment's variable costs per battery pack as shown in Figure 5. Labor cost, dictated by process times, is the most significant variable cost driver for both pre-treatment processes. Assuming plant operators are employed for the duration of each process, thermal labor costs total $\$ 46.63$ per battery pack while mechanical labor costs total $\$ 121.80$ per battery pack. The 1-hour process time for the industrial drying step accounts for the bulk of this cost $\$ 90$. To highlight the process time difference, mechanical pre-treatment requires a minimum 80 minutes per battery pack while thermal requires a minimum of 30 minutes. Energy costs are minimal per battery pack - $\$ 1.70$ for 
mechanical and $\$ 2.48$ for thermal. If drying time can be reduced or another method implemented to separate the active materials from the current collectors, then mechanical pre-treatment could be more competitive from a variable cost perspective.

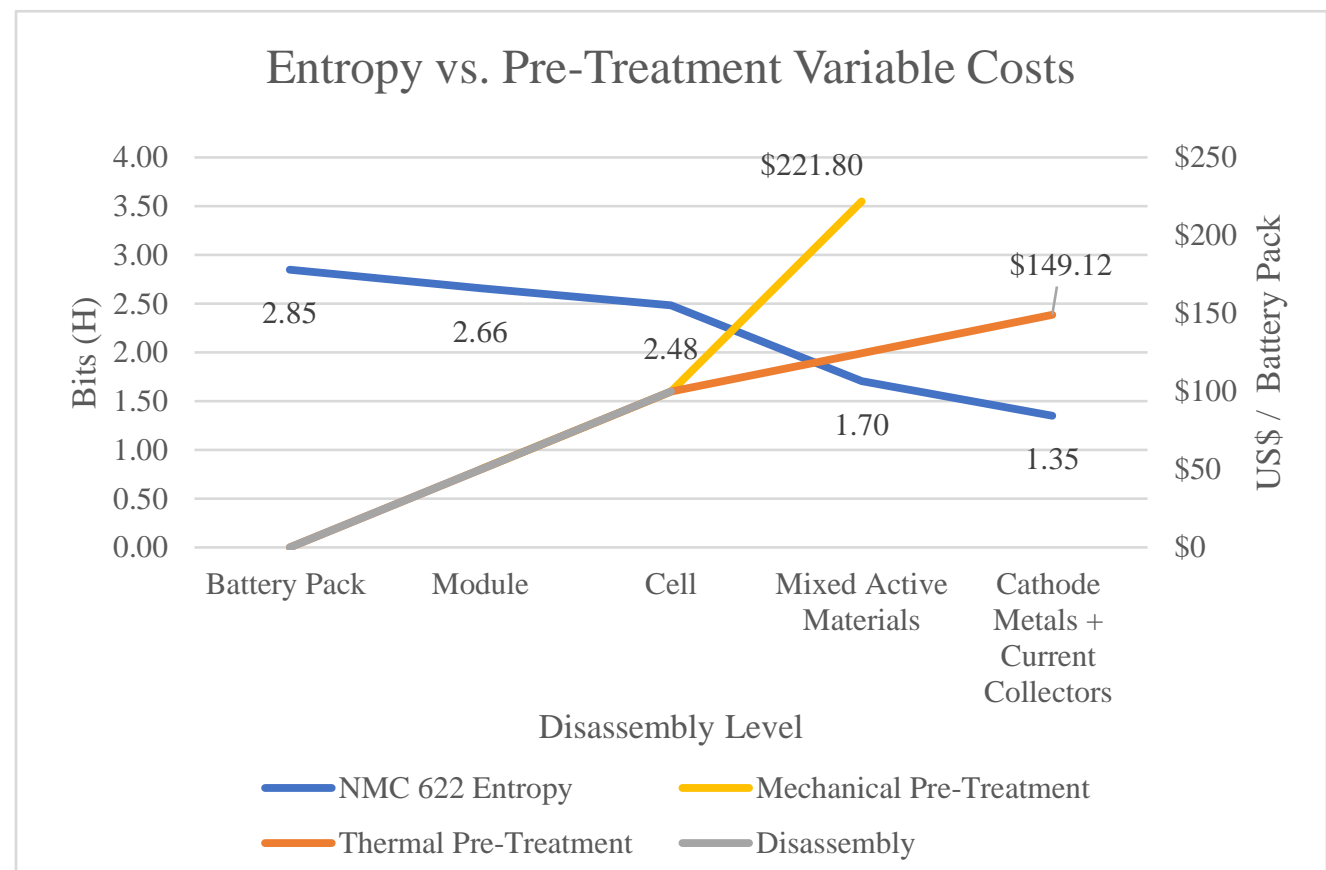

Figure 5: Entropy vs. Pre-Treatment Variable Costs - Mechanical Pre-Treatment is almost 1.5 as expensive (\$221.80 vs. \$149.12) than Thermal Pre-Treatment per battery pack and achieves 0.35 bits less entropy reduction. Thermal Pre-Treatment is a much more cost-efficient process for reducing statistical entropy.

Outside of the pre-treatment process, disassembly still represents a significant variable cost per battery pack. For disassembly, two high voltage technicians working for two hours results in $\$ 100$ per pack - representing anywhere from $40-50 \%$ to upwards of $70 \%$ of total variable costs in Figure 5. Previous works have emphasized the disassembly labor cost sensitivity, suggesting reversible joining between components and the use of standard fasteners and bolts instead of welds can reduce disassembly time (Gaines and Dunn, 2014). Looking at cost efficiencies in reducing entropy, thermal's high entropy reduction (1.13 bits) combined with short process time, i.e. fewer labor hours, make it the most cost-effective pre-treatment method - $\$ 43.47$ per bit - compared to Mechanical's $\$ 156.15$ per bit. Disassembly is the least cost-efficient step \$277.78 per bit - highlighting again the importance of labor costs (See Appendix B.3).

\subsection{Flow Rates, Process Times and Equipment Capacity}

While thermal pre-treatment observes favorable variable costs compared to mechanical, a combination of other factors influences battery recycling economics. Flow rates - the number of battery packs processed in an amount of 
time - are dictated by individual equipment process times and equipment capacity at each step. By optimizing flow rates, time-based labor costs can be allocated across more battery packs, reducing variable cost per battery pack. In the present analysis, pre-treatment processes are not comparable on an equipment capacity basis, which impacts the ability to allocate variable costs. Equipment capacity is also not a variable cost; rather, it requires capital costs that are not evaluated in this study. The authors recognize that thermal pretreatment equipment, i.e. gas-fired furnaces, will bear greater capital costs than mechanical pre-treatment machines. This is economically unfavorable for thermal and advantageous to mechanical.

\subsection{Maximum Recoverable Metal Value}

Mechanical pre-treatment maintains favorable maximum recoverable metal value over thermal pre-treatment in all recovery scenarios since mechanical recovers lithium in addition to nickel, cobalt, and copper. Comparing mechanical's lower recovery efficiency $(72.5 \%)$ to thermal's higher recovery efficiency $(90 \%)$, mechanical reports a maximum recoverable metal value of $\$ 1809.42$ per battery pack - still $16 \%$ higher than thermal's value. When mechanical pre-treatment's higher bound of recovery efficiency $(80 \%)$ is compared to thermal pre-treatment's lower bound (80\%), mechanical achieves a maximum recoverable metal value $42 \%$ higher than thermal pre-treatment (See Appendix D.1). Results are sensitive to price fluctuations and potential differences in each metal's recovery efficiency. As mentioned in Section 2.7, the same recovery efficiency is assumed for all metals in each recovery efficiency scenario.

To determine which metal price has the greatest impact on the maximum recoverable metal value results, a sensitivity analysis for metal price fluctuations was performed (See Appendix D.2). Maximum recoverable metal values for both processes are most sensitive to cobalt prices, which serve as the value driver for battery recycling as discussed in Section 3.1. Between the two processes, thermal pre-treatment is $1.4 \mathrm{x}$ more sensitive to cobalt prices than mechanical pre-treatment, meaning a change in cobalt prices has a greater impact on thermal pre-treatment profitability than mechanical pre-treatment.

\section{Conclusions for Recyclability}

This analysis establishes that EV battery packs are attractive sources of cobalt, copper, lithium and nickel based on favorable metal concentrations, often 10x higher than economic ores. The pre-treatment processes to recover these metals have respective trade-offs between energy consumption, product purity, variable cost and maximum recoverable metal value. Our analysis suggests that the defining differences between the pre-treatment processes are process time and lithium recovery, which influence variable costs and maximum recoverable metal value respectively. Thermal pre-treatment reduces statistical entropy to a greater extent than mechanical pre-treatment, producing a purer feedstock for 
hydrometallurgical recovery; however, it only recovers one of the strategic metals - cobalt - and not lithium. Mechanical pre-treatment allows for lithium recovery, which increases maximum recoverable metal value, but bears higher processing times that increase variable labor costs per battery pack. Both pretreatment processes remain highly sensitive to cobalt prices, thermal more so than mechanical.

Apart from economics, policy can play a crucial role in determining which pretreatment process becomes more prevalent. Existing policy, most notably the 2006 EU Battery Directive, was designed primarily for portable electronics before the rise of larger format BEV battery packs. Research is needed in the policy arena to determine the appropriate balance of regulation for BEV battery packs, such as design practices for recycling and even labelling or designating battery components such that recyclers understand the materials arriving at their facilities (Gaines, 2014). Regulation on hazardous material disposal can also influence where and how pre-treatment processes are adopted. While future policy is uncertain, pre-treatment processes exist, and the BEV battery pack is an attractive source of metals that bear strategic and economic importance. 


\section{Appendices}

Appendix A.1: Metal Pricing Data

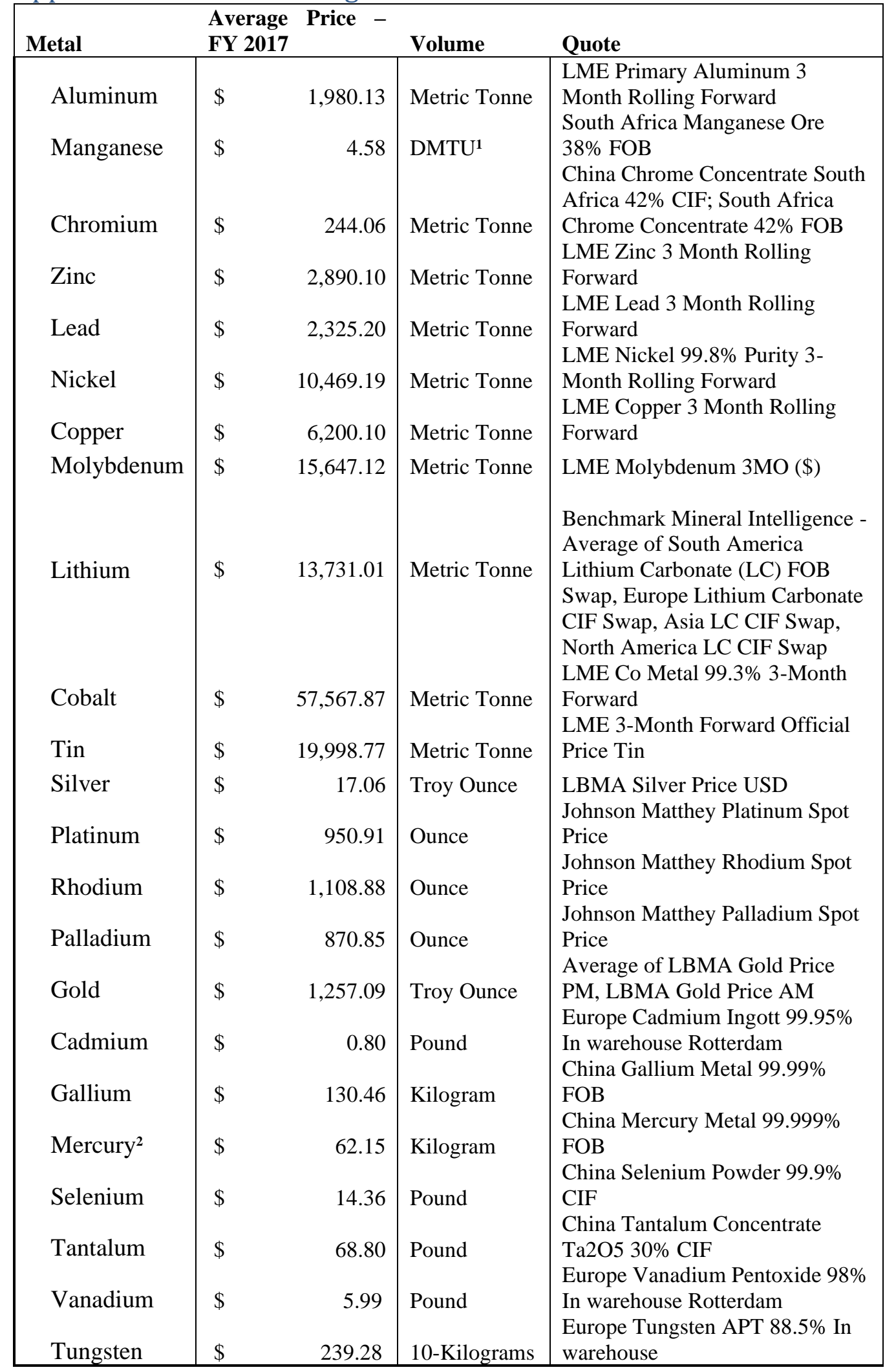


${ }^{1}$ Dry Metric Ton

${ }^{2}$ Originally quoted in Chinese Yuan (CNY); Converted to USD at CNY-to-USD Exchange Rate: 6.718

\begin{tabular}{|c|c|c|c|}
\hline Metal & $\begin{array}{l}\text { Lower } \\
\text { Bound }\end{array}$ & $\begin{array}{l}\text { Upper } \\
\text { Bound }\end{array}$ & Source \\
\hline Aluminum & 0.2 & 0.3 & $\begin{array}{l}\text { (The International Aluminium Institute, } \\
\text { 2018) }\end{array}$ \\
\hline Manganese & 0.1 & 0.54 & (Matricardi and Downing, 2012) \\
\hline Chromium & 0.11 & 0.27 & (Papp and Lipin, 2010) \\
\hline Zinc & 0.02 & 0.12 & (Goodwin and by Staff, 2012) \\
\hline Lead & 0.02 & 0.06 & (King et al., 2014) \\
\hline Nickel & 0.003 & 0.0095 & (Tisserant and Pauliuk, 2016) \\
\hline Copper & 0.003 & 0.01 & (Tisserant and Pauliuk, 2016) \\
\hline Molybdenum & 0.2 & 0.4 & (Steifel, 2010) \\
\hline Lithium & 0.0006 & 0.009 & (Mohr et al., 2012) \\
\hline Cobalt & 0.0003 & 0.01 & (Tisserant and Pauliuk, 2016) \\
\hline Tin & 0.00015 & 0.009 & (Gaver, 2013) \\
\hline Silver & 0.000015 & 0.00003 & (Rudenno, 2012) \\
\hline PGE - 4E 1 & 0.00000117 & 0.0000048 & (Mudd, 2012) \\
\hline Gold & 0.000001 & 0.000008 & (Rudenno, 2012) \\
\hline Cadmium & 0.0005 & 0.008 & (Schulte-Schrepping and Piscator, 2000) \\
\hline Gallium & 0.000003 & 0.000008 & (Greber, 2000) \\
\hline Mercury & 0.002 & 0.035 & (Simon et al., 2006) \\
\hline Selenium & 0.0001 & 0.0004 & (Hoffmann and King, 2010) \\
\hline Tantalum & 0.0002 & 0.0004 & (Albrecht et al., 2011) \\
\hline Vanadium & 0.01 & 0.02 & (Baroch and by Staff, 2013) \\
\hline Tungsten & 0.005 & 0.02 & (Penrice, 2010) \\
\hline
\end{tabular}

${ }^{1}$ Based on (grams per metric ton) ore reserves of "4E" - Platinum, Palladium, Rhodium, and Gold 
Appendix A.3: Cobalt, Copper, and Nickel Grades by Ore Type

\begin{tabular}{|c|c|c|c|}
\hline Ore Type & $\begin{array}{c}\text { Cobalt } \\
\text { Grades }\end{array}$ & Copper Grades & Nickel Grades \\
\hline Cobalt-Copper & $0.27 \%$ & $1.11 \%$ & N/A \\
\hline Cobalt-Nickel & $0.08 \%$ & N/A & $0.95 \%$ \\
\hline Cobalt-Copper-Nickel & $0.03 \%$ & $0.40 \%$ & $0.61 \%$ \\
\hline Cobalt & $1.00 \%$ & N/A & N/A \\
\hline Copper & N/A & $0.71 \%$ & N/A \\
\hline Nickel & N/A & N/A & $0.88 \%$ \\
\hline Copper-Nickel & N/A & $0.31 \%$ & $0.34 \%$ \\
\hline
\end{tabular}


Appendix B.1: Equipment List

\begin{tabular}{|c|c|c|c|c|c|}
\hline $\begin{array}{c}\text { Pre- } \\
\text { Treatment } \\
\text { Process }\end{array}$ & $\begin{array}{c}\text { Machine } \\
\text { Type }\end{array}$ & $\begin{array}{c}\text { Machine } \\
\text { Brand and } \\
\text { Model }\end{array}$ & Machine Size & $\begin{array}{c}\text { Power / } \\
\text { Energy } \\
\text { Requireme } \\
\text { nt }\end{array}$ & $\begin{array}{c}\text { Work } \\
\text { Time Per } \\
\text { Battery } \\
\text { Pack (hrs) }\end{array}$ \\
\hline N/A & $\begin{array}{l}\text { Conveyor } \\
\text { Belt }\end{array}$ & $\begin{array}{l}\text { Hytrol® } \\
\text { Model TA } \\
\text { 6'L Slider } \\
\text { Bed } \\
\text { Conveyor }\end{array}$ & $\begin{array}{l}\text { Belt width: } 20 " \text {; } \\
\text { Belt length: } 60 "\end{array}$ & $0.5 \mathrm{HP}$ & $0.018^{1}$ \\
\hline Mechanical & Shredder & $\begin{array}{l}\text { Untha RS30 } \\
\text { 4-Shaft } \\
\text { Shredding } \\
\text { System }\end{array}$ & $\begin{array}{l}450 \mathrm{~mm} \times 600 \\
\mathrm{~mm}\end{array}$ & 22. $\mathrm{kW}$ & 0.018 \\
\hline Mechanical & $\begin{array}{l}\text { Air } \\
\text { Classifier }\end{array}$ & $\begin{array}{l}\text { Aveka Model } \\
\text { No. } 500\end{array}$ & $\begin{array}{l}900 \mathrm{~kg} / \mathrm{hr} \text { feed } \\
\text { rate }\end{array}$ & $90.0 \mathrm{HP}$ & 0.32 \\
\hline Mechanical & $\begin{array}{l}\text { Cutting } \\
\text { Mill }\end{array}$ & $\begin{array}{l}\text { Retsch } \\
\text { Cutting Mill } \\
\text { SM } 400\end{array}$ & $\begin{array}{l}170 \mathrm{~mm} \times 220 \\
\mathrm{~mm}\end{array}$ & $3.0 \mathrm{~kW}$ & 0.32 \\
\hline Mechanical & $\begin{array}{l}\text { Drying } \\
\text { Oven }\end{array}$ & $\begin{array}{l}\text { Lewco } \\
\text { EWT03ED- } \\
60-60-72\end{array}$ & $60^{\prime \prime}$ x 60" x 72" & $45.0 \mathrm{~kW}$ & 1.0 \\
\hline Mechanical & $\begin{array}{l}\text { Drying } \\
\text { Oven - } \\
\text { Fan }\end{array}$ & Lewco Inc. & N/A & $2.0 \mathrm{HP}$ & 1.0 \\
\hline Mechanical & $\begin{array}{l}\text { Vibrating } \\
\text { Sieve }\end{array}$ & $\begin{array}{l}\text { Russell Finex } \\
\text { Separator }\end{array}$ & 30 " diameter & $1.5 \mathrm{HP}$ & 0.37 \\
\hline Thermal & $\begin{array}{l}\text { Gas-Fired } \\
\text { Furnace }\end{array}$ & N/A & N/A & $0.69 \mathrm{mmbtu}^{2}$ & 0.50 \\
\hline
\end{tabular}

${ }^{1}$ For energy consumption, work time is multiplied by the number of conveyor belts present in each pre-treatment process described in Appendix C.2: Pre-Treatment Processes.

${ }^{2}$ Energy requirement per metric ton of battery scrap

Appendix B.2: Separation Steps Energy Efficiency per Bit of Entropy

\begin{tabular}{|l|c|l|c|}
\hline Separation Step & $\begin{array}{l}\text { Entropy } \\
\text { Reduced } \\
\text { (Bits) }\end{array}$ & $\begin{array}{l}\text { Energy } \\
\text { Consumed } \\
\text { (kWh) }\end{array}$ & kWh / Bit \\
\hline Manual Disassembly & 0.36 & 2.22 & 6.08 \\
\hline $\begin{array}{l}\text { Mechanical Pre- } \\
\text { Treatment }\end{array}$ & 0.78 & 26.08 & 33.44 \\
\hline $\begin{array}{l}\text { Thermal Pre- } \\
\text { Treatment }\end{array}$ & 1.13 & 71.29 & 63.09 \\
\hline
\end{tabular}


Appendix B.3: Separation Steps Cost Efficiency per Bit of Entropy

\begin{tabular}{|c|c|c|c|c|c|}
\hline Separation Step & $\begin{array}{l}\text { Entropy } \\
\text { Reduced } \\
\text { (Bits) }\end{array}$ & Cost & & $\$ / \mathbf{B i}$ & \\
\hline $\begin{array}{l}\text { Manual } \\
\text { Disassembly }\end{array}$ & 0.36 & $\$$ & 100.00 & $\$$ & 277.78 \\
\hline $\begin{array}{l}\text { Mechanical Pre- } \\
\text { Treatment }\end{array}$ & 0.78 & $\$$ & 121.80 & $\$$ & 156.15 \\
\hline $\begin{array}{l}\text { Thermal Pre- } \\
\text { Treatment }\end{array}$ & 1.13 & $\$$ & 49.12 & $\$$ & 43.47 \\
\hline
\end{tabular}

Appendix C.1: Disassembly Levels

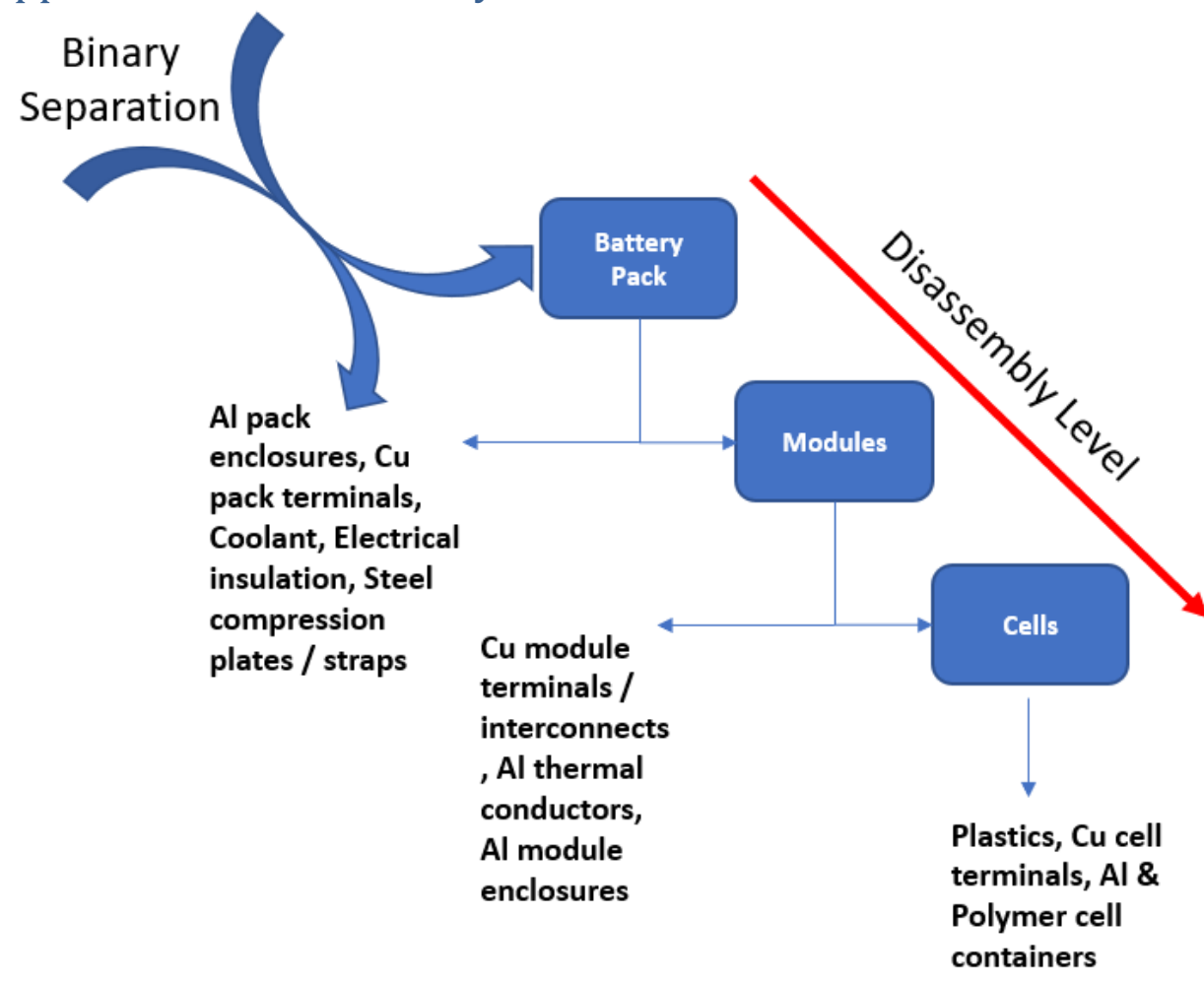



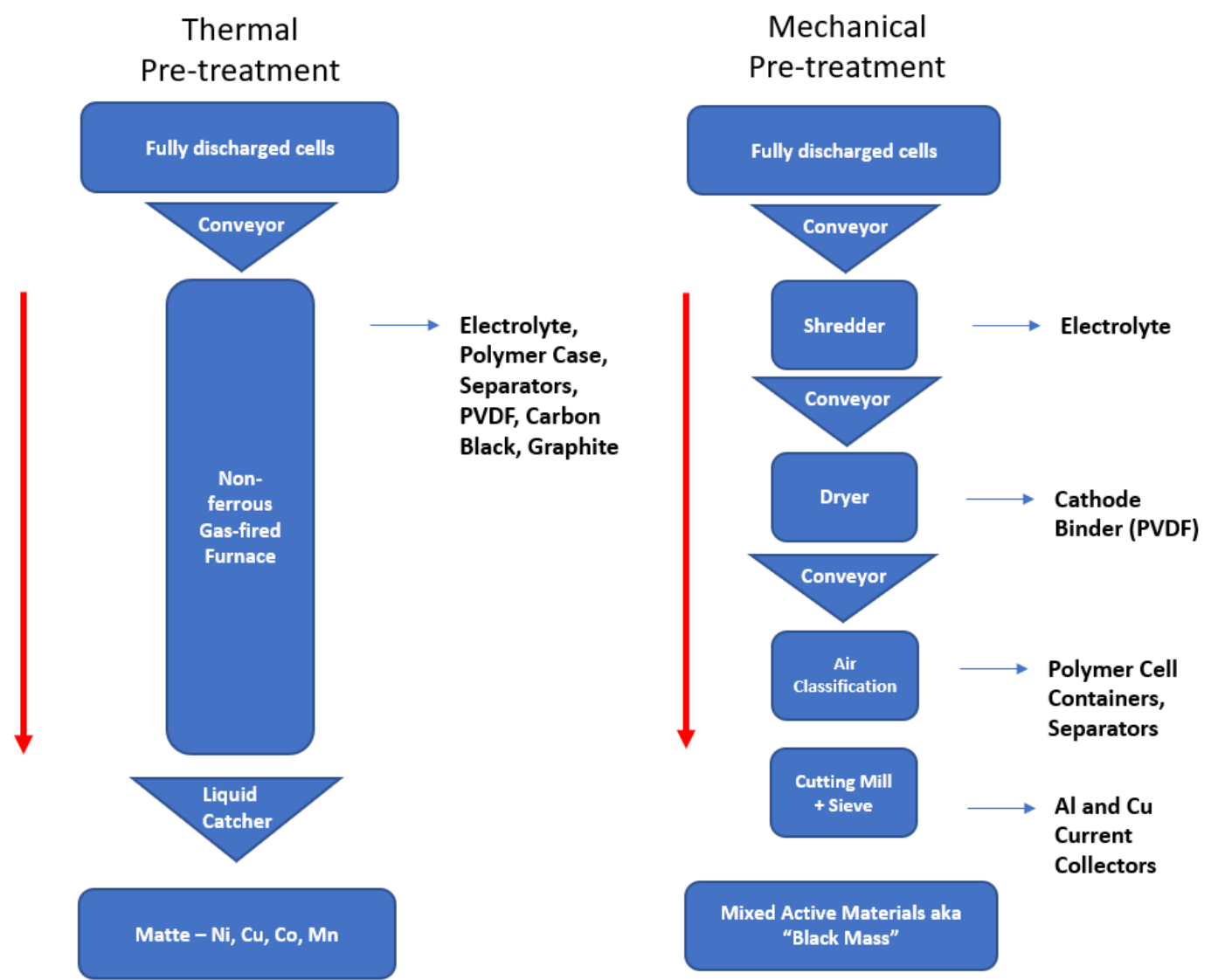
Appendix C.3: The LiB Recycling Process
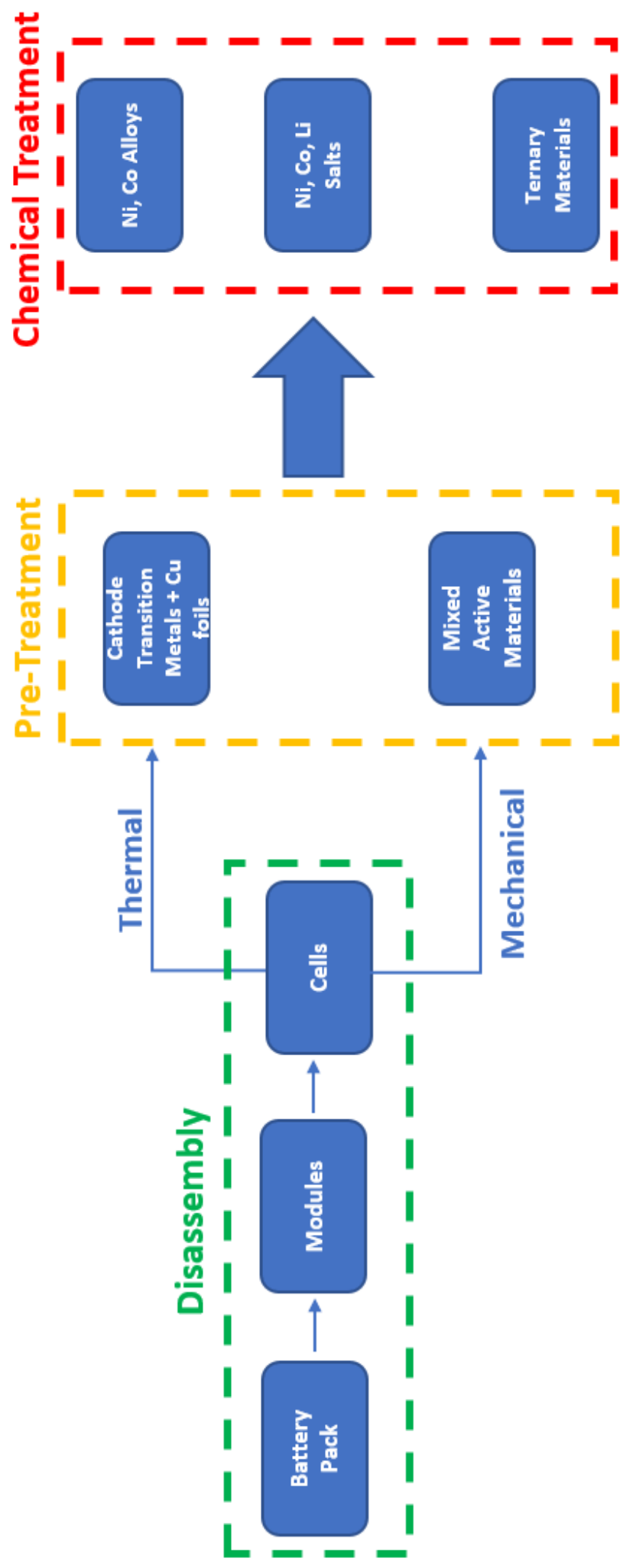
Appendix D.1: Economic Recovery Scenarios

Thermal Pre-Treatment - LOW

\begin{tabular}{|c|c|c|c|c|c|c|}
\hline Metal & $\begin{array}{l}\text { Amount } \\
\text { Availabl } \\
\text { e (Kg) }\end{array}$ & $\begin{array}{l}\text { Thermal } \\
\text { Efficiency }\end{array}$ & $\begin{array}{l}\text { Recovere } \\
\text { d (Kg) }\end{array}$ & $\begin{array}{l}\text { FY17 } \\
\text { Market } \\
\text { Price \$/Kg }\end{array}$ & Value & \\
\hline Lithium & 50.63 & $80.0 \%$ & N/A & N/A & N/A & \\
\hline Nickel & 42.46 & $80.0 \%$ & 33.97 & \$ 10.47 & $\$$ & 355.63 \\
\hline Cobalt & 14.21 & $80.0 \%$ & 11.37 & $\$ 57.57$ & $\$$ & 654.61 \\
\hline Copper $^{2}$ & 51.14 & $80.0 \%$ & 40.91 & 6.20 & $\$$ & 253.67 \\
\hline $\begin{array}{l}\text { Copper } \\
\text { (Disassembly) } \\
3\end{array}$ & 2.85 & $90.0 \%$ & 2.57 & 6.20 & $\$$ & 15.90 \\
\hline $\begin{array}{l}\text { Aluminum } \\
\text { (Disassembly) } \\
3\end{array}$ & 63.89 & $90.0 \%$ & 57.50 & 1.98 & $\$$ & 113.85 \\
\hline
\end{tabular}

Maximum Recoverable Metal Value $\quad \$ 1,393.66$

Thermal Pre-Treatment - HIGH

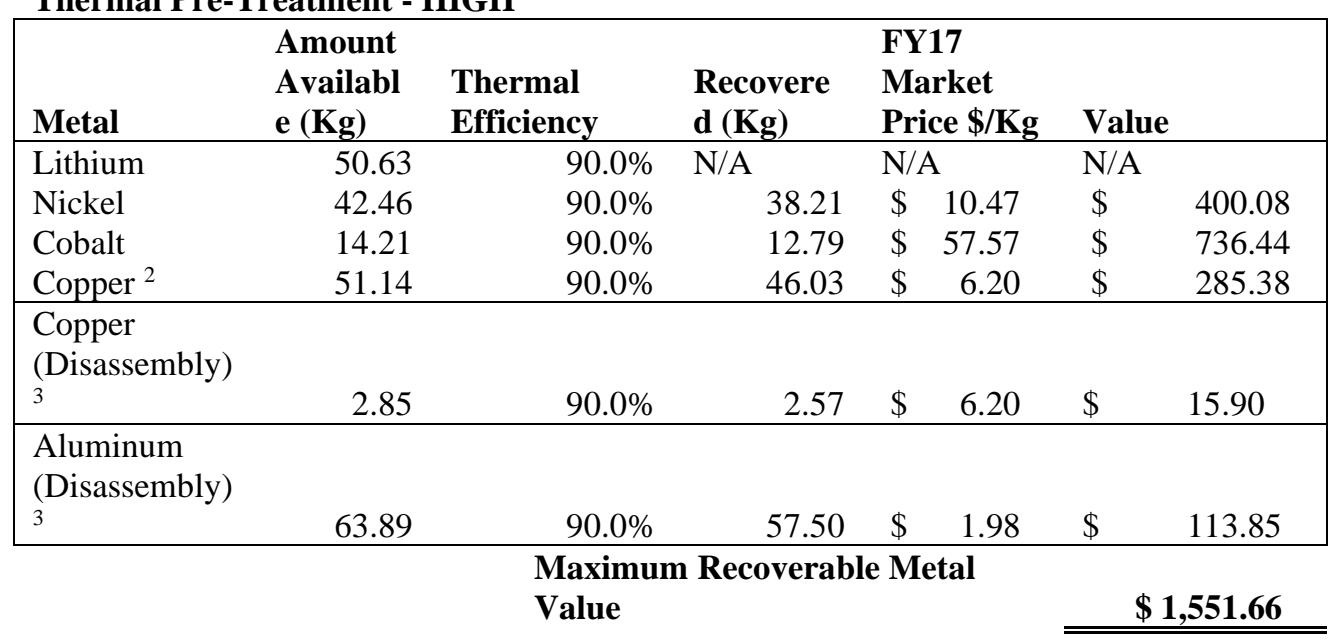


Mechanical Pre-Treatment - LOW

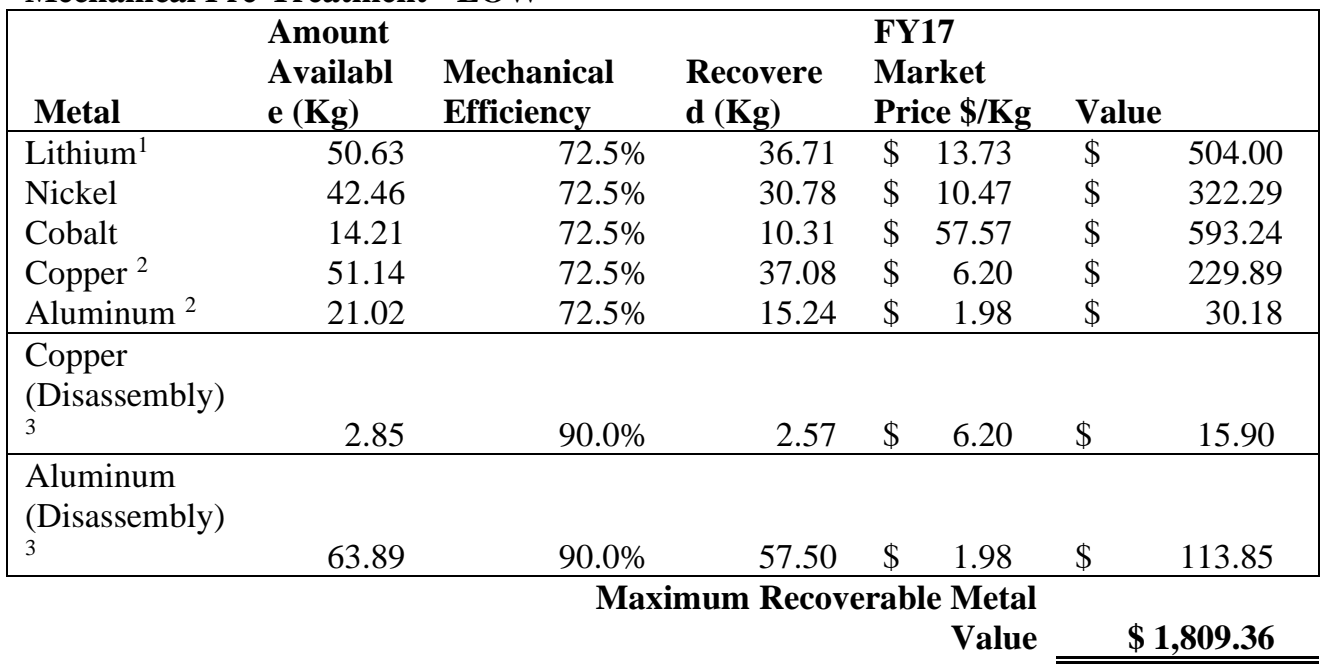

Mechanical Pre-Treatment - HIGH

\begin{tabular}{|c|c|c|c|c|c|c|}
\hline Metal & $\begin{array}{l}\text { Amount } \\
\text { Available } \\
(\mathrm{Kg})\end{array}$ & $\begin{array}{l}\text { Mechanica } \\
\text { l Efficiency }\end{array}$ & $\begin{array}{l}\text { Recovere } \\
\text { d (Kg) }\end{array}$ & $\begin{array}{l}\text { FY17 } \\
\text { Market } \\
\text { Price \$/Kg }\end{array}$ & Value & \\
\hline Lithium $^{1}$ & 50.63 & $80.0 \%$ & 40.85 & $\$ 13.73$ & $\$$ & 555.86 \\
\hline Nickel & 42.46 & $80.0 \%$ & 33.97 & $\$ 10.47$ & $\$$ & 355.63 \\
\hline Cobalt & 14.21 & $80.0 \%$ & 11.37 & $\$ \quad 57.57$ & $\$$ & 654.61 \\
\hline Copper $^{2}$ & 51.14 & $80.0 \%$ & 40.91 & 6.20 & $\$$ & 253.67 \\
\hline Aluminum $^{2}$ & 21.02 & $80.0 \%$ & 16.82 & 1.98 & $\$$ & 33.30 \\
\hline $\begin{array}{l}\text { Copper } \\
\text { (Disassembly) } \\
3\end{array}$ & 2.85 & $90.0 \%$ & 2.57 & 6.20 & $\$$ & 15.90 \\
\hline $\begin{array}{l}\text { Aluminum } \\
\text { (Disassembly) }\end{array}$ & 63.89 & $90.0 \%$ & 57.50 & 1.98 & $\$$ & 113.85 \\
\hline & & $\mathrm{Ma}$ & 8 & $\begin{array}{r}\text { rable Metal } \\
\text { Value }\end{array}$ & & 983.17 \\
\hline
\end{tabular}

${ }^{1}$ Lithium value is based on lithium carbonate prices. Lithium carbonate is displayed in "Amount Available (Kg)" and "Recovered (Kg)." Elemental lithium is converted into lithium carbonate quantity by multiplying by 5.32 .

2 Calculated as contained metal in the cells; Excludes contained metal at the module and battery pack level

${ }^{3}$ Calculated as metal in the module and battery pack levels that are recovered during manual disassembly. 
Appendix D.2: Metal Price Sensitivity Analyses

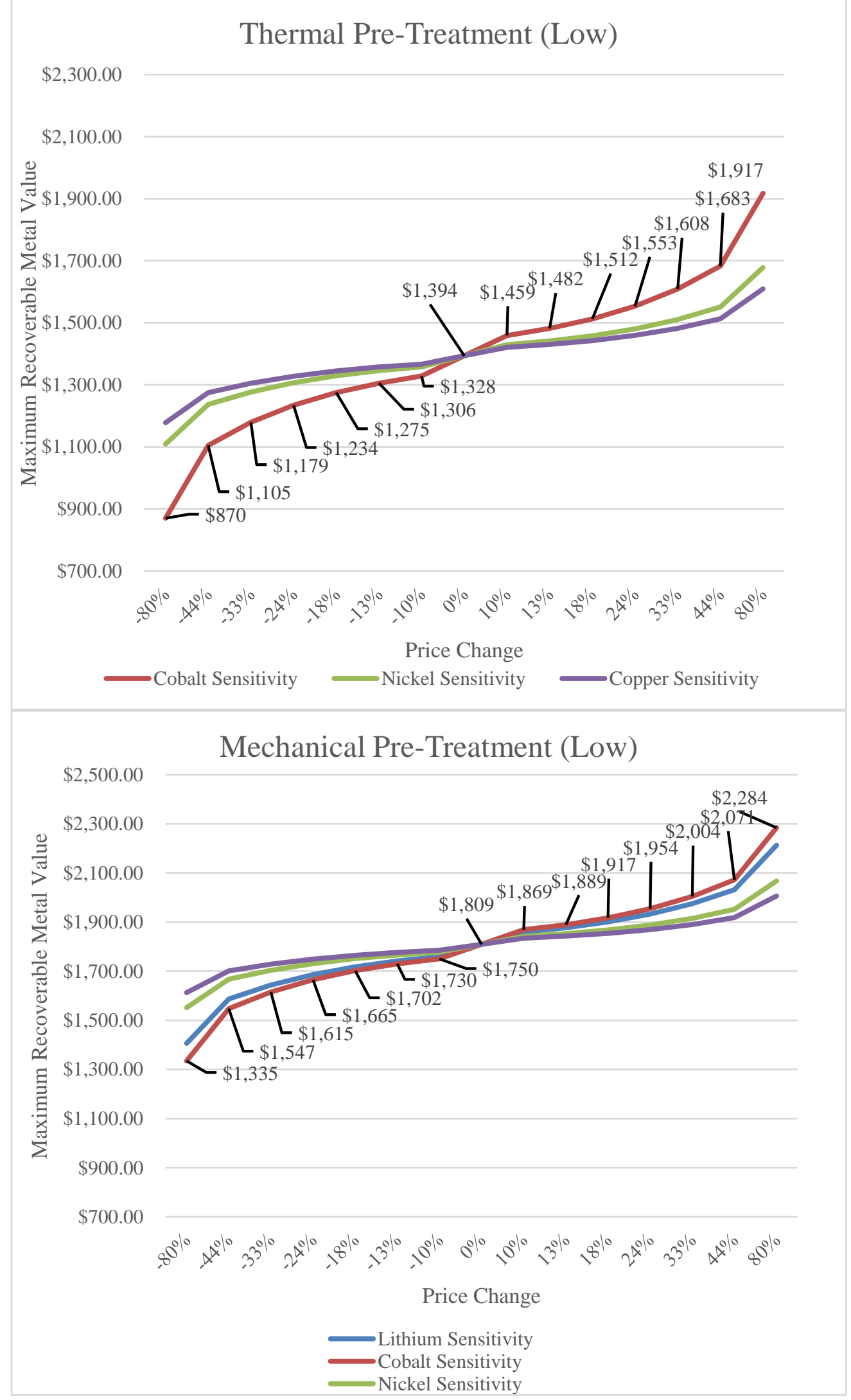




\section{Bibliography}

Albrecht, S., Cymorek, C., Andersson, K., Reichert, K., Wolf, R., 2011. Tantalum and Tantalum Compounds, in: Ullmann's Encyclopedia of Industrial Chemistry. American Cancer Society. https://doi.org/10.1002/14356007.a26_071.pub2

ALLEN, D.T., Behmanesh, N., 1994. Waste as Raw Materials, in: Allenby, B.R., Richards, D.J. (Eds.), The Greening of Industrial Ecosystems. National Academy Press, Washington, D.C., pp. 69-89.

Baroch, E.F., by Staff, U., 2013. Vanadium and Vanadium Alloys, in: KirkOthmer Encyclopedia of Chemical Technology. American Cancer Society, pp. 1-18. https://doi.org/10.1002/0471238961.22011401.a01.pub3

Bradley, D.C., Stillings, L.L., Jaskula, B.W., Munk, L., McCauley, A.D., 2017. Lithium, in: Critical Mineral Resources of the United States - Economic and Environmental Geology and Prospects for Future Supply: U.S. Geological Survey Professional Paper 1802. pp. K1-K21. https://doi.org/https://doi.org/10.3133/pp1802K

Charles, R.G., Douglas, P., Hallin, I.L., Matthews, I., Liversage, G., 2017. An investigation of trends in precious metal and copper content of RAM modules in WEEE: Implications for long term recycling potential. Waste Manag. 60, 505-520. https://doi.org/10.1016/J.WASMAN.2016.11.018

Chen, X., Ma, H., Luo, C., Zhou, T., 2017. Recovery of valuable metals from waste cathode materials of spent lithium-ion batteries using mild phosphoric acid. J. Hazard. Mater. 326, 77-86. https://doi.org/10.1016/j.jhazmat.2016.12.021

Ciez, R.E., Whitacre, J.F., 2019. Examining different recycling processes for lithium-ion batteries. Nat. Sustain. 2, 148-156. https://doi.org/10.1038/s41893-019-0222-5

Commission, E., 2017. Communication from the Commission to the European Parliament, the Council, the European Economic and Social Committee and the Committee of the Regions on the 2017 list of Critical Raw Materials for the EU. Brussels.

Contestabile, M., Panero, S., Scrosati, B., 2001. A laboratory-scale lithium-ion battery recycling process. J. Power Sources 92, 65-69. https://doi.org/10.1016/S0378-7753(00)00523-1

Cucchiella, F., D'Adamo, I., Lenny Koh, S.C., Rosa, P., 2015. Recycling of WEEEs: An economic assessment of present and future e-waste streams. Renew. Sustain. Energy Rev. 51, 263-272. 
https://doi.org/10.1016/J.RSER.2015.06.010

Dahmus, J.B., Gutowski, T.G., 2007. What Gets Recycled: An Information Theory Based Model for Product Recycling. Environ. Sci. Technol. 41, 7543-7550. https://doi.org/10.1021/es062254b

Diekmann, J., Hanisch, C., Frobose, L., Schalicke, G., Loellhoeffel, T., Folster, A.-S., Kwade, A., 2017. Ecological Recycling of Lithium-Ion Batteries from Electric Vehicles with Focus on Mechanical Processes. J. Electrochem. Soc. 164, A6184-A6191. https://doi.org/10.1149/2.0271701jes

Diekmann, J., Loellhoeffel, T., Kwade, A., 2018. Realization in a Demonstration Plant, in: Kwade, A., Diekmann, J. (Eds.), Recycling of Lithium-Ion Batteries: The LithoRec Way. Springer International Publishing, Cham, pp. 247-251. https://doi.org/10.1007/978-3-31970572-9_14

Dunn, J.B., Gaines, L.L., Barnes, M., Sullivan, J., Wang, W., 2014. Material and Energy Flows in the Materials Production, Assembly, and End-of-Life Stages of the Automotive Lithium-Ion Battery Life Cycle. Argonne, Illinois.

Gaines, L., 2018. Lithium-ion battery recycling processes: Research towards a sustainable course. Sustain. Mater. Technol. 17, e00068. https://doi.org/10.1016/J.SUSMAT.2018.E00068

Gaines, L., 2014. The future of automotive lithium-ion battery recycling: Charting a sustainable course. Sustain. Mater. Technol. 1-2, 2-7. https://doi.org/10.1016/J.SUSMAT.2014.10.001

Gaines, L.L., Dunn, J.B., 2014. Lithium-Ion Battery Environmental Impacts, in: Lithium-Ion Batteries. Elsevier, pp. 483-508. https://doi.org/10.1016/B978-0-444-59513-3.00021-2

Gaver, C.C., 2013. Tin and Tin Alloys, in: Kirk-Othmer Encyclopedia of Chemical Technology. American Cancer Society, pp. 1-19. https://doi.org/10.1002/0471238961.20091407012205.a01.pub3

Goodwin, F.E., by Staff, U., 2012. Zinc and Zinc Alloys, in: Kirk-Othmer Encyclopedia of Chemical Technology. American Cancer Society, pp. 147. https://doi.org/10.1002/0471238961.2609140307151504.a01.pub3

Graedel, T.E., Allwood, J., Birat, J., Buchert, M., Hagelüken, C., Reck, B.K., Sibley, S.F., Sonnemann, G., n.d. What Do We Know About Metal Recycling Rates? J. Ind. Ecol. 15, 355-366. https://doi.org/10.1111/j.1530-9290.2011.00342.x

Gratz, E., Sa, Q., Apelian, D., Wang, Y., 2014. A closed loop process for 
recycling spent lithium ion batteries. J. Power Sources 262, 255-262. https://doi.org/10.1016/j.jpowsour.2014.03.126

Greber, J.F., 2000. Gallium and Gallium Compounds, in: Ullmann's Encyclopedia of Industrial Chemistry. American Cancer Society. https://doi.org/10.1002/14356007.a12_163

Gu, F., Guo, J., Yao, X., Summers, P.A., Widijatmoko, S.D., Hall, P., 2017. An investigation of the current status of recycling spent lithium-ion batteries from consumer electronics in China. J. Clean. Prod. 161, 765-780. https://doi.org/10.1016/J.JCLEPRO.2017.05.181

Hanulik, J., 1995. Process for the recycling of batteries, especially dry batteries. US6009817A.

Herrmann, C., Raatz, A., Mennenga, M., Schmitt, J., Andrew, S., 2012. Assessment of Automation Potentials for the Disassembly of Automotive Lithium Ion Battery Systems, in: Dornfeld, D.A., Linke, B.S. (Eds.), Leveraging Technology for a Sustainable World. Springer Berlin Heidelberg, Berlin, Heidelberg, pp. 149-154.

Hoffmann, J.E., King, M.G., 2010. Selenium and Selenium Compounds, in: Kirk-Othmer Encyclopedia of Chemical Technology. American Cancer Society, pp. $1-36$. https://doi.org/10.1002/0471238961.1905120508150606.a01.pub3

Holland, H.D., Petersen, U., 1995. Mineral Commodities, Living Dangerously: The Earth, Its Resources and The Environment. Princeton University Press, Princeton, New Jersey.

Johnson, J., Harper, E.M., Lifset, R., Graedel, T.E., 2007. Dining at the Periodic Table: Metals Concentrations as They Relate to Recycling. Environ. Sci. Technol. 41, 1759-1765. https://doi.org/10.1021/es060736h

Jones, J., Schmitt, R.J., Goodwill, J.E., Koller, J., 1997. Understanding Electric Arc Furnace Operations. The EPRI Center for Materials Production, Pittsburgh.

King, M., Ramachandran, V., Prengaman, R.D., DeVito, S.C., Breen, J., Staff, U. by, 2014. Lead and Lead Alloys, in: Kirk-Othmer Encyclopedia of Chemical Technology. American Cancer Society, pp. 1-55. https://doi.org/10.1002/0471238961.1205010411091407.a01.pub3

Kushnir, D.C.U. of T., 2015. Lithium ion battery recycling technology 2015: Current state and future prospects. Environmental systems analysis report \#2015:18.

Lee, C.K., Rhee, K.-I., 2003. Reductive leaching of cathodic active materials from lithium ion battery wastes. Hydrometallurgy 68, 5-10. 
https://doi.org/10.1016/S0304-386X(02)00167-6

Li, L., Bian, Y., Zhang, X., Xue, Q., Fan, E., Wu, F., Chen, R., 2018. Economical recycling process for spent lithium-ion batteries and macroand micro-scale mechanistic study. J. Power Sources 377, 70-79. https://doi.org/10.1016/J.JPOWSOUR.2017.12.006

Li, L., Ge, J., Wu, F., Chen, R., Chen, S., Wu, B., 2010. Recovery of cobalt and lithium from spent lithium ion batteries using organic citric acid as leachant. J. Hazard. Mater. 176, 288-293. https://doi.org/10.1016/J.JHAZMAT.2009.11.026

Lizin, S., Van Dael, M., Van Passel, S., 2017. Battery pack recycling: Behaviour change interventions derived from an integrative theory of planned behaviour study. Resour. Conserv. Recycl. 122, 66-82. https://doi.org/10.1016/J.RESCONREC.2017.02.003

Matricardi, L.R., Downing, J., 2012. Manganese and Manganese Alloys, in: Kirk-Othmer Encyclopedia of Chemical Technology. American Cancer Society, $\mathrm{pp}$. $1-27$. https://doi.org/10.1002/0471238961.1301140713012018.a01.pub3

Mohamed Sultan, A.A., Lou, E., Mativenga, P.T., 2017. What should be recycled: An integrated model for product recycling desirability. J. Clean. Prod. 154, 51-60. https://doi.org/10.1016/J.JCLEPRO.2017.03.201

Mohr, S.H., Mudd, G.M., Giurco, D., 2012. Lithium Resources and Production: Critical Assessment and Global Projections. Miner. . https://doi.org/10.3390/min2010065

Mudd, G.M., 2012. Key trends in the resource sustainability of platinum group elements. Ore Geol. Rev. 46, 106-117. https://doi.org/10.1016/J.OREGEOREV.2012.02.005

Nelson, Paul; Gallagher, Kevin; Bloom, Ira; Dees, Dennis; Ahmed, S., 2018. BatPaC Version 3.1 June 2018.

Olivetti, E.A., Ceder, G., Gaustad, G.G., Fu, X., 2017. Lithium-Ion Battery Supply Chain Considerations: Analysis of Potential Bottlenecks in Critical Metals. Joule 1, 229-243. https://doi.org/10.1016/J.JOULE.2017.08.019

Ordoñez, J., Gago, E.J., Girard, A., 2016. Processes and technologies for the recycling and recovery of spent lithium-ion batteries. Renew. Sustain. Energy Rev. 60, 195-205. https://doi.org/10.1016/J.RSER.2015.12.363

Papp, J.F., Lipin, B.R., 2010. Chromium and Chromium Alloys, in: KirkOthmer Encyclopedia of Chemical Technology. American Cancer Society, pp. 1-47. https://doi.org/10.1002/0471238961.0308181523051920.a01.pub3 
Penrice, T.W., 2010. Tungsten and Tungsten Alloys, in: Kirk-Othmer Encyclopedia of Chemical Technology. American Cancer Society, pp. 115. https://doi.org/10.1002/0471238961.2021140716051418.a01.pub3

Rudenno, V., 2012. The mining valuation handbook: mining and energy valuation for investors and management, 4th ed. John Wiley \& Sons Australia, Ltd., Melbourne.

Schobert, H.H., 2014. Energy and Society: An Introduction, Second Edition, 2nd ed. CRC Press.

Schulte-Schrepping, K.-H., Piscator, M., 2000. Cadmium and Cadmium Compounds, in: Ullmann's Encyclopedia of Industrial Chemistry. American Cancer Society. https://doi.org/10.1002/14356007.a04_499

Shannon, C.E., Weaver, W., 1964. The Mathematical Theory of Communication, First. ed. The Univeristy of Illinois Press, Urbana.

Sherman, E., 2018. Volkswagen Says It Can Build 15 Million Electric Cars in the Next Few Years. Fortune Mag.

Sherwood, T.K., Ryan, J.M., 1959. Mass transfer to a turbulent fluid with and without chemical reaction. Chem. Eng. Sci. 11, 81-91. https://doi.org/10.1016/0009-2509(59)80001-4

Shin, S.M., Kim, N.H., Sohn, J.S., Yang, D.H., Kim, Y.H., 2005. Development of a metal recovery process from Li-ion battery wastes. Hydrometallurgy 79, 172-181. https://doi.org/10.1016/J.HYDROMET.2005.06.004

Simon, M., Jönk, P., Wühl-Couturier, G., Halbach, S., 2006. Mercury, Mercury Alloys, and Mercury Compounds, in: Ullmann's Encyclopedia of Industrial Chemistry. American Cancer Society. https://doi.org/10.1002/14356007.a16_269.pub2

Sloop, S.E., Trevey, J., Gaines, L.L., Lerner, M.M., Xu, W., 2018. Advances in Direct Recycling of Lithium-Ion Electrode Materials. Electrochem. Soc. 85, 397-403. https://doi.org/10.1149/08513.0397ecst

Sonoc, A., Jeswiet, J., Soo, V.K., 2015. Opportunities to Improve Recycling of Automotive Lithium Ion Batteries. Procedia CIRP 29, 752-757. https://doi.org/10.1016/J.PROCIR.2015.02.039

Steifel, E.I., 2010. Molybdenum and Molybdenum Alloys, in: Kirk-Othmer Encyclopedia of Chemical Technology. American Cancer Society, pp. 116. https://doi.org/10.1002/0471238961.1315122504150114.a01.pub3

The International Aluminium Institute, 2018. Refining Process [WWW Document]. URL http://bauxite.world-aluminium.org/refining/process/

Tisserant, A., Pauliuk, S., 2016. Matching global cobalt demand under different 
scenarios for co-production and mining attractiveness. J. Econ. Struct. 5, 4. https://doi.org/10.1186/s40008-016-0035-x

Turk, D., Cazzola, P., 2018. Global EV Outlook 2018 - Towards cross modal electrification.

Tytgat, J., 2013. The Recycling Efficiency of Li-ion EV batteries according to the European Commission Regulation, and the relation with the End-ofLife Directive recycling rate. World Electr. Veh. J. 6, 1039-1047.

U.S. Energy Information Administration, 2019a. Table 1.2. Summary Statistics for the United States, 2007 - 2017 [WWW Document]. URL https://www.eia.gov/electricity/annual/html/epa_01_02.html

U.S. Energy Information Administration, 2019b. Natural Gas Prices [WWW Document]. URL https://www.eia.gov/dnav/ng/ng_pri_sum_dcu_nus_a.htm

Wall Howard, P., 2019. Ford plans electric vehicle production at Flat Rock, adding 900 jobs. Detroit Free Press.

Wang, X., Gaustad, G., Babbitt, C.W., Bailey, C., Ganter, M.J., Landi, B.J., 2014. Economic and environmental characterization of an evolving Li-ion battery waste stream. J. Environ. Manage. 135, 126-134. https://doi.org/10.1016/J.JENVMAN.2014.01.021

Yao, Y., Zhu, M., Zhao, Z., Tong, B., Fan, Y., Hua, Z., 2018. Hydrometallurgical Processes for Recycling Spent Lithium-Ion Batteries: A Critical Review. ACS Sustain. Chem. Eng. 6, 13611-13627. https://doi.org/10.1021/acssuschemeng.8b03545

Zeng, X., Li, J., 2016a. Measuring the recyclability of e-waste: an innovative method and its implications. J. Clean. Prod. 131, 156-162. https://doi.org/10.1016/J.JCLEPRO.2016.05.055

Zeng, X., Li, J., 2016b. Measuring the recyclability of e-waste: an innovative method and its implications. J. Clean. Prod. 131, 156-162. https://doi.org/10.1016/J.JCLEPRO.2016.05.055

Zeng, X., Li, J., Singh, N., 2014. Recycling of Spent Lithium-Ion Battery: A Critical Review. Crit. Rev. Environ. Sci. Technol. 44, 1129-1165. https://doi.org/10.1080/10643389.2013.763578

Zhan, R., Oldenburg, Z., Pan, L., 2018. Recovery of active cathode materials from lithium-ion batteries using froth flotation. Sustain. Mater. Technol. 17, e00062. https://doi.org/10.1016/J.SUSMAT.2018.E00062

Zuo, L., Wang, C., Corder, G.D., 2019. Strategic evaluation of recycling hightech metals from urban mines in China: An emerging industrial perspective. J. Clean. Prod. 208, 697-708. 
https://doi.org/10.1016/J.JCLEPRO.2018.10.030

阿部大造 富岡功, 1993. Method for recovering cobalt from used lithium secondary battery. JP2920810B2. 